\title{
A Systematic Review of Global Alpha-Tocopherol Status as Assessed by Nutritional Intake Levels and Blood Serum Concentrations
}

\author{
Szabolcs Péter ${ }^{1}$, Angelika Friedel ${ }^{1}$, Franz F. Roos ${ }^{1}$, Adrian Wyss ${ }^{1}$, Manfred \\ Eggersdorfer ${ }^{1}$, Kristina Hoffmann $^{2}$, and Peter Weber ${ }^{1}$
}

'DSM Nutritional Products Ltd., Kaiseraugst, Switzerland ${ }^{2}$ Mannheim Institute of Public Health, Social and Preventive Medicine, Medical Faculty Mannheim, Heidelberg University, Mannheim, Germany

Received: September 16, 2015; Accepted: November 11, 2015

\begin{abstract}
The purpose of this study is to systematically review the published literature reporting vitamin E intake levels and serum concentrations in order to obtain a global overview of $\alpha$-tocopherol status. Articles published between 2000 and 2012 were considered; 176 articles referring to 132 single studies were included. Applying an RDA (recommended daily allowance) of $15 \mathrm{mg} /$ day and EAR (estimated average requirement) of $12 \mathrm{mg} /$ day to all populations with a minimum age of 14 years, 82 and $61 \%$ of mean and median data points were below the RDA and the EAR, respectively. Regarding serum concentrations, globally $13 \%$ of the included data points were below the functional deficiency threshold concentration of $12 \mu \mathrm{mol} / \mathrm{L}$, mostly for newborns and children. Several prospective observational studies suggest that a serum $\alpha$-tocopherol concentration of $\geq 30 \mu \mathrm{mol} / \mathrm{L}$ has beneficial effects on human health. Of the reported study populations and subpopulations, only $21 \%$ reached this threshold globally. This systematic review suggests that the $\alpha$-tocopherol status is inadequate in a substantial part of the studied populations.
\end{abstract}

Keywords: alpha-tocopherol, vitamin E, intake, serum, global, status

\section{Introduction}

The term vitamin $\mathrm{E}$ covers eight compounds found in nature $(\alpha-, \beta-, \gamma-, \delta$-tocopherol, and $\alpha-, \beta-, \gamma-$, $\delta$-tocotrienol). Of the eight naturally occurring forms of vitamin $\mathrm{E}, \alpha$-tocopherol is the main form retained in human plasma [1,2]. Vitamin E is a powerful, chainbreaking antioxidant, which is localized due to its lipophilic nature in lipid compartments such as cell 
membranes. There it prevents the peroxidation of lipids [3] and thus preserves cellular membrane integrity. Vitamin E also plays a crucial role in the stability of erythrocytes and the conductivity of central and peripheral nerves $[4,5]$. It prevents hemolytic anemia and neurological symptoms of vitamin E deficiency (e.g., ataxia, peripheral neuropathy, myopathy, pigmented retinopathy). This essential role of vitamin $\mathrm{E}$ as an antioxidant in the human body has recently been underscored by the approval of a 13.1 European Food Safety Authority (EFSA) health claim [6].

Dietary intake recommendations for vitamin $\mathrm{E}$ are established in many countries. In the US, the Recommended Daily Allowance (RDA) is $15 \mathrm{mg}$ $\alpha$-tocopherol in adults for both men and women. This value is derived from the amount needed to prevent peroxide-induced hemolysis in vitamin E-deficient subjects, which was determined from a limited number of studies performed and published in the $1950 \mathrm{~s}$ and $1960 \mathrm{~s}$ to occur at $12 \mu \mathrm{mol} / \mathrm{L}$ serum $\alpha$-tocopherol [7-9]. In subjects fed with a vitamin E-deficient diet for over 6 years, an intake of $12 \mathrm{mg} \alpha$-tocopherol per day was sufficient to achieve this serum $\alpha$-tocopherol concentration, which was then defined as the estimated average requirement (EAR) and became the basis to calculate the RDA. A daily intake of $12 \mathrm{mg}$ $\alpha$-tocopherol was also considered sufficient to protect polyunsaturated fatty acids (PUFAs) [1]. Dietary intake surveys in the US report mean daily $\alpha$-tocopherol intakes of only $6.9 \mathrm{mg}$, suggesting that the majority of people in the US do not achieve the recommended daily intake [10]. However, inaccuracy of such studies must also be taken into consideration when interpreting the results. A recent review reported that in the UK and the US more than $75 \%$ of the population do not meet the recommended daily intake [11]. Although dietary intake surveys are widely used to assess the nutrient status of populations, they have limitations because of possible underreporting, quality of food composition database used, etc. [12].

Measuring $\alpha$-tocopherol serum concentrations is another approach to assess its status. At serum $\alpha$-tocopherol concentrations below $8 \mu \mathrm{mol} / \mathrm{L}$, manifest clinical symptoms of vitamin deficiency are reported, such as peripheral neuropathy, spinocerebellar ataxia, and skeletal myopathy [1]. Low plasma $\alpha$-tocopherol concentrations are also associated with increased odds of mild cognitive impairment and Alzheimer's disease [13]. There is limited evidence on $\alpha$-tocopherol serum concentrations needed to avoid manifest (about $8 \mu \mathrm{mol} / \mathrm{L})$ or functional $(12 \mu \mathrm{mol} / \mathrm{L})$ deficiencies in the human body. However, an increasing number of studies report $\alpha$-tocopherol serum concentrations at which beneficial effects may occur. Findings from the National Health and Nutrition Examination Survey (NHANES) cohort report $\alpha$-tocopherol serum concentrations below $20 \mu \mathrm{mol} / \mathrm{L}$ in $32 \%$ of the participants. This threshold concentration is preferred by some experts [14]. Results from a number of observational prospective studies have suggested additional benefits of $\alpha$-tocopherol at or above $30 \mu \mathrm{mol} / \mathrm{L}$ serum concentration, with proposed applications including prevention of cardiovascular disease and different types of cancer [15-20]. This $\alpha$-tocopherol serum concentration of $\geq 30 \mu \mathrm{mol} / \mathrm{L}$ as a desirable target for health benefits is further supported by the fact that urine excretion of $\alpha$-carboxyethyl hydroxychroman $(\alpha-\mathrm{CEHC})$, a metabolite and status marker of $\alpha$-tocopherol [21], increases when under healthy conditions an $\alpha$-tocopherol serum threshold of $30 \mu \mathrm{mol} / \mathrm{L}$ is exceeded [1]. In addition, pentane concentration in the exhaled air (a marker of oxidative stress) is inversely related to vitamin $\mathrm{E}$ intakes and is very low at $\alpha$-tocopherol serum concentrations of $30 \mu \mathrm{mol} / \mathrm{L}$ [22]. The beneficial effects associated with these serum concentrations have been acknowledged by the common recommendations of the German-speaking countries Germany, Austria, and Switzerland, which have set the desired $\alpha$-tocopherol serum concentrations at or above $30 \mu \mathrm{mol} / \mathrm{L} \mathrm{[23].}$

However, insights from earlier reviews on vitamin E status are limited due to reporting only on, for example, specific geographic regions, age groups, or risk groups. Thus, in order to better understand the current $\alpha$-tocopherol provision worldwide, we systematically review in this study existing and reported data on vitamin $\mathrm{E}$ intakes and serum concentrations in the general population globally, focusing on age groups and sex in different countries.

\section{Methods \\ Literature search}

We searched the Pubmed/Medline database for original articles on vitamin $\mathrm{E}$ status in the general population using Medical Subject Headings (MeSH) terms and free text. Keywords were chosen from the $\mathrm{MeSH}$ thesaurus. Free-text terms were searched in all fields (title, abstract, and other fields in PubMed). The following search strategy was applied: ("vitamin E”[MeSH terms] OR "vitamin E”[all fields] OR “alpha-tocopherol"[all fields] OR "beta-tocopherol”[all fields] OR "gamma- tocopherol"[all fields] OR 

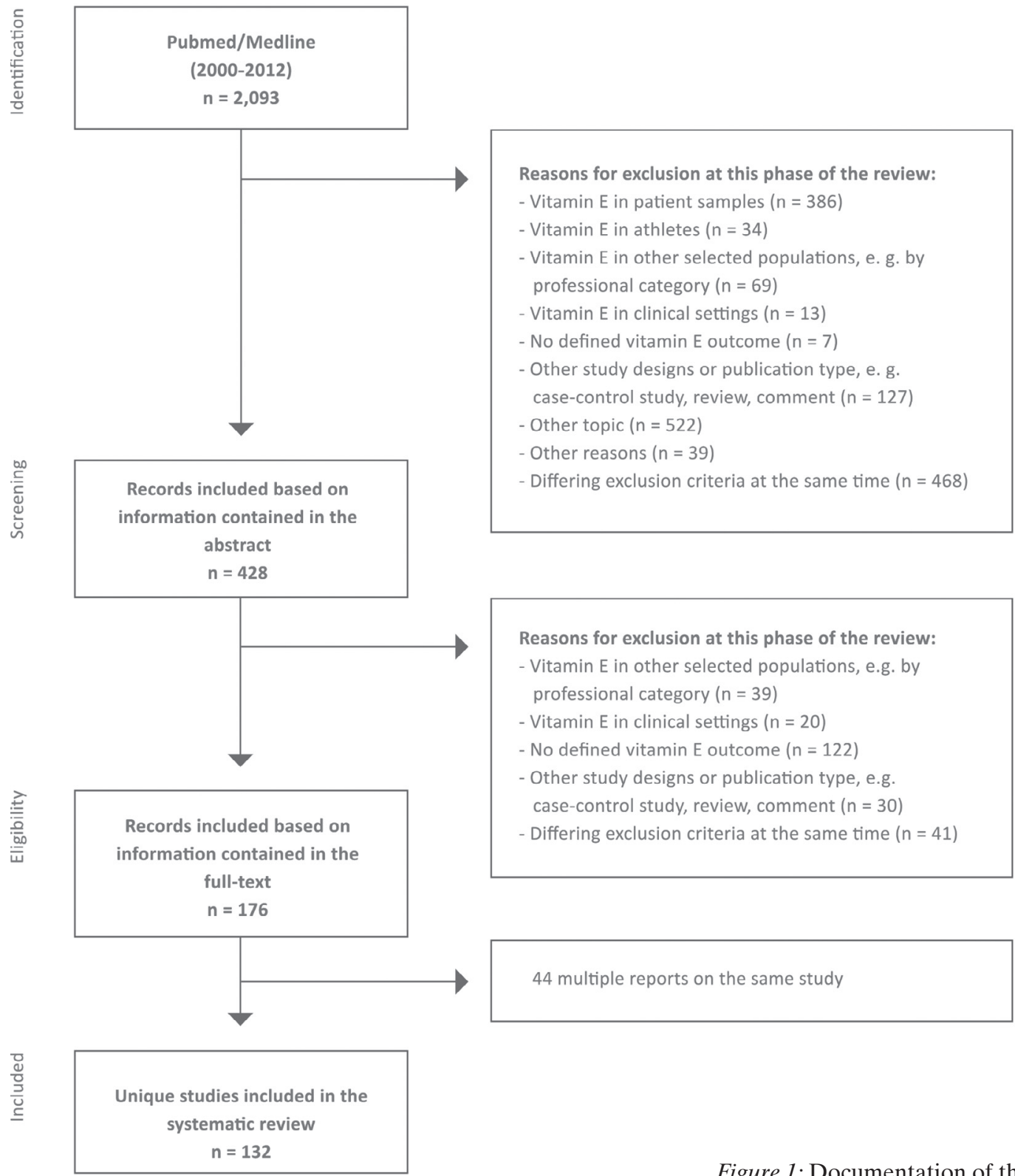

Figure 1: Documentation of the selection process.

"tocotrienol"[all fields]) AND ("blood"[subheading] OR "nutrition assessment"[MeSH terms] OR "nutritional status"[MeSH terms] OR “epidemiologic studies"[MeSH terms] OR “population-based”[all fields] OR "population"[all fields] OR "survey"[all fields] OR "representative"[all fields] OR "crosssectional"[all fields] OR "observational"[all fields]) NOT ("case reports"[publication type] OR "case-control studies"[MeSH terms] OR "clinical trial"[publication type] OR "review"[publication type]) AND "humans"[MeSH terms] AND English[lang] AND ("2000/01/01”[PDAT] : “2012/06/30”[PDAT]). Articles published between 01.01.2000 and 30.07.2012 were considered. We excluded articles published before 2000 because of a probable general change in eating habits, particularly in low- and middle-income countries [24]. This exclusion might also have caused a shift in mean-population vitamin E intake levels and serum concentrations. The final screen on 30.07.2012 produced 2,093 hits. Wherever possible, the methods used in this review follow the Preferred Reporting Items For Systematic Reviews And Meta-Analyses (PRISMA) Statement [25]. 


\section{Study selection}

The outcome of interest was the vitamin E status assessed by nutritional intake level and/or by plasma or serum concentration of all vitamin $\mathrm{E}$ forms, with particular focus on $\alpha$-tocopherol. Eligible studies included samples of randomly selected persons from the healthy general population all over the world. We considered subgroups of the population by age, sex, and geographic region, as well as by ethnicity, diet type, smoking, and physical activity status. However, studies on patients and thus clinical settings and athletes were excluded from this review because of presumably different demands on vitamin $\mathrm{E}$ intake not representing the healthy general population. To be included, studies had to have a cross-sectional design or provide baseline data of a population-based cohort. Study types such as clinical trials, case-control studies, case reports, case series, or reviews were excluded. The selection of records was performed independently by two scientists. Inter-rater agreement was good, and disagreements were discussed and resolved by consensus in all cases (abstract selection: kappa $=0.683$; full-text selection: kappa $=0.630)$. After completion of both selection procedures, 176 records were included based on information contained in the full-text articles. The flow chart on records that were identified, included, or excluded in this review is provided in Figure 1.

\section{Data extraction, calculations, and statistical analysis}

We used a standardized extraction form to retrieve data from a wide range of variables, such as study characteristics, details on study population and recruitment strategies, and vitamin $E$ values assessed by nutritional intake levels and/or by plasma or serum concentrations. We also retrieved data from study quality, such as response rate, information about selection bias, and validity of the instrument used to assess nutritional intake. Data from most studies were represented in the data set by a single entry for the total study population. However, since several studies did not publish a single consensus value, we also considered subentries (values for subgroups reported within a study). We included multiple subentries for a single study if data were presented by subgroups of interest such as age or sex.

We refer to the term "vitamin E" as reported in the selected publications, which often do not differentiate between the different isoforms (e.g. $\alpha$-tocopherol and $\gamma$-tocopherol) but rather use vitamin $\mathrm{E}$ as a gen- eral term instead, including all eight isomers. For consistency and comparability, we converted intake measurements to $\mathrm{mg} /$ day and blood measurements of status to $\mu \mathrm{mol} / \mathrm{L}$. Since the Dietary Reference Intakes of the Institute of Medicine (IOM) from the US are well established, generally accepted, and globally referenced among scientists, we have chosen to apply these values $(\mathrm{RDA}=15 \mathrm{mg} /$ day and $\mathrm{EAR}=12 \mathrm{mg} /$ day) to evaluate the vitamin $\mathrm{E}$ intake in this systematic review [1]. The EAR is the amount of a nutrient that meets the requirement of adequacy for half of the individuals in different subgroups of the population (e. g., of a given age, sex, or physiological condition). This is a median value since the amount of the nutrient needed to achieve adequacy varies between individuals. A person whose nutrient intake is below the EAR has a $50-100 \%$ risk of inadequacy. The RDA is the average daily nutrient intake level that meets the requirements of nearly all healthy persons of a certain population subgroup. If an individual has an intake less than the RDA but more than the EAR, his or her risk of inadequacy falls between $2-3$ and $50 \%$ [1]. Considering this, in the present review we have applied both reference values with a focus on the RDA. For serum concentrations needed to avoid functional deficiency [7-9] and at which beneficial effects possibly occur [15-20], we applied serum $\alpha$-tocopherol concentrations of $<12 \mu \mathrm{mol} / \mathrm{L}$ and $\geq 30$ $\mu \mathrm{mol} / \mathrm{L}$. Since $\alpha$-tocopherol is the main form retained in human plasma, and $\gamma$-tocopherol degrades rapidly [1] and has low serum concentrations, we reported descriptive information on $\gamma$-tocopherol. We did not, however, pursue further analyses of $\gamma$-tocopherol. In humans, plasma $\alpha$-tocopherol concentrations are generally 4-10 times higher than those of $\gamma$-tocopherol [26]. Furthermore, it is well described that plasma $\gamma$-tocopherol is suppressed by $\alpha$-tocopherol supplementation $[27,28]$. However, serum concentrations of $\gamma$-tocopherol that are lower than $\alpha$-tocopherol do not necessarily reflect lower potency of $\gamma$-tocopherol on possible functional outcomes.

The focus of this review is on descriptive analyses. Thus, we calculated descriptive statistics and presented the distribution of categorical data using frequencies and percentages. Where applicable, overall means and proportions were weighted by taking the individual sample sizes into account. Statistical analyses and visualizations were performed in SAS 9.2 (SAS Institute Inc., Cary, NC, USA, 2002-2008) and in the $\mathrm{R}$ statistics software version 2.15.2 [29]. 


\section{Results}

\section{Description of studies}

Altogether 176 articles [30-205] referring to 132 single studies were included in this review, with a total of 249,637 participants from 46 countries. Subgroups by age, sex, geographic region, ethnicity, diet type, smoking, and physical activity status were considered. The 176 articles reported 1,419 discrete values on vitamin $\mathrm{E}$ intake levels or serum concentrations. They ranged from overall values for the total study population to values for specific subgroups, which we define as subentries. Thus it is possible that a value of a single individual contributes to multiple subentries. In case of an elderly female, for example, she contributes to the mean value of the total population, of the subgroup of females, and of her age group. The sample size of individual studies ranged from 10 to 48,776 participants, with a median of $n=374$. While the majority of studies included data on males and females, 5 studies $(3.8 \%)$ restricted their focus to males and 13 studies (9.9\%) contained data on females only. The overall proportion of males and females was $36.0 \%$ and $64.0 \%$, respectively. On average, participants had a mean age of 49.8 years, ranging from 0 (newborns) to 106 years. The age group of older adults (aged $50+$ years) was considered in $27.3 \%$ of the studies, followed by middle-aged adults (aged 35-49 years; $20.7 \%$ ) and adults in general, including younger adults (aged $18+$ years; $15.7 \%$ ). Most of the studies were conducted in Europe (47.7\%), followed by North America (24.2\%), and the Western Pacific region $(14.8 \%)$ (Table I). The highest number of publications derived from the periodically repeated NHANES $(n=13)$. Of the 132 studies, about one fourth included participants taking vitamin supplements that could potentially influence the reported serum concentrations. However, supplement use was not sufficiently reported in half of the studies.

\section{Description of vitamin E measurements}

56 studies $(42.4 \%)$ provided nutritional intake data, with $81.3 \%$ of the corresponding subentries referring to vitamin $\mathrm{E}$ as such. Food frequency questionnaires were used in $36.1 \%$ of these studies, followed by $24-\mathrm{h}$ recalls $(31.9 \%)$ and dietary records $(20.8 \%)$. A method used to a lesser extent was dietary history (6.9\%). In $63.4 \%$ of intake values no adjustment had been performed, $27.1 \%$ of intake values were ener- gy-adjusted, $8.0 \%$ represented a tocopherol-energy ratio, and $0.6 \%$ a tocopherol-PUFA ratio. 59 studies $(44.7 \%)$ provided data on vitamin E status measured in blood, with most of them reporting $\alpha$-tocopherol concentrations $58.2 \%$ of the corresponding subentries). In $97.3 \%$ of these studies, HPLC was used for the measurements. In $60.4 \%$ of blood values no adjustment for blood lipids had been performed; $29.0 \%$ of blood values represented a tocopherol-lipid ratio and $10.6 \%$ of blood values had been adjusted for lipids. 17 studies $(12.9 \%)$ included both intake data and status measured in blood.

\section{Global status}

A descriptive analysis of intakes and blood concentrations of different isoforms of vitamin $\mathrm{E}$ is presented in Table II. Nutritional intake was analyzed for unadjusted $\alpha$ - and $\gamma$-tocopherol and all eight isomers together. The median intake was $6.2 \mathrm{mg} /$ day for $\alpha$-tocopherol, and $1 \mathrm{mg} /$ day for $\gamma$-tocopherol. For intake of all eight isomers together the median was $10.2 \mathrm{mg} /$ day. For circulating $\alpha$ - and $\gamma$-tocopherol concentrations, the unadjusted medians were $22.1 \mu \mathrm{mol} / \mathrm{L}$ and $2.2 \mu \mathrm{mol} / \mathrm{L}$, respectively, and the lipid-adjusted medians were 27.4 $\mu \mathrm{mol} / \mathrm{L}$ and $4.9 \mu \mathrm{mol} / \mathrm{L}$, respectively. For all eight isomers together, the unadjusted median was $22.1 \mu \mathrm{mol} / \mathrm{L}$ and the lipid-adjusted median was $22.6 \mu \mathrm{mol} / \mathrm{L}$ (no significant difference, $\mathrm{p}=0.63$ after correction for age group).

Table I: Number of studies (sorted by descending frequency) on vitamin $\mathrm{E}$ status by world region, as assessed by intake levels and serum concentrations. $\mathrm{N}=128$ studies; 4 studies were excluded from the regional data set because it was not clear where the study population had been recruited $[40,81,115,202]$.

\begin{tabular}{lcc}
\hline World region & $\mathrm{n}$ (studies) & \% (studies) \\
\hline Europe (including Russia, & 61 & 47.7 \\
Turkey, and Israel) & & \\
North America & 31 & 24.2 \\
Western Pacific Region & 19 & 14.8 \\
Africa & 6 & 4.7 \\
Eastern Mediterranean Region & 6 & 4.7 \\
Latin America & 3 & 2.3 \\
(including Mexico) & & \\
South East Asia Region & 2 & 1.6 \\
\hline
\end{tabular}


Table II: Descriptive analysis for vitamin E values estimated from nutritional intake (mg/day) and measured in blood ( $\mu \mathrm{mol} / \mathrm{L})$ globally $(\mathrm{n}=132$ studies $)$.

\begin{tabular}{|c|c|c|c|c|c|c|}
\hline \multirow{3}{*}{$\begin{array}{l}\text { Vitamin E } \\
\text { form } \\
\alpha \text {-tocopherol }\end{array}$} & \multirow{2}{*}{\multicolumn{2}{|c|}{$\frac{\text { Nutritional intake }}{\text { Unadjusted }}$}} & \multicolumn{4}{|c|}{ Serum concentrations } \\
\hline & & & \multicolumn{2}{|c|}{ Unadjusted } & \multicolumn{2}{|c|}{ Lipid adjusted } \\
\hline & $\begin{array}{c}\mathrm{n} \\
\text { (subentries) }\end{array}$ & $\begin{array}{c}\text { Median [Min; Max] } \\
\text { mg/day }\end{array}$ & $\begin{array}{c}\mathrm{n} \\
\text { (subentries) }\end{array}$ & $\begin{array}{c}\text { Median [Min; Max] } \\
\mu \mathrm{mol} / \mathrm{L}\end{array}$ & $\begin{array}{c}\mathrm{n} \\
\text { (subentries) }\end{array}$ & $\begin{array}{c}\text { Median [Min; Max }] \\
\mu \mathrm{mol} / \mathrm{L}\end{array}$ \\
\hline All & 88 & $6.2[1.7 ; 76.1]$ & 199 & $22.1[5.3 ; 42.2]$ & 29 & $27.4[19.9 ; 34.2]$ \\
\hline Male & 24 & $6.6[4.0 ; 76.1]$ & 46 & $20.1[6.2 ; 33.9]$ & 5 & $24.4[19.9 ; 27.8]$ \\
\hline Female & 30 & $5.0[1.7 ; 66.7]$ & 56 & $22.6[6.4 ; 42.2]$ & 5 & $25.4[23.3 ; 28.3]$ \\
\hline $\begin{array}{l}\text { Mixed } \\
\gamma \text {-tocopherol }\end{array}$ & 34 & $6.6[4.1 ; 20.8]$ & 97 & $24.2[5.3 ; 40.3]$ & 19 & $29.9[20.6 ; 34.2]$ \\
\hline All & 9 & $1.0[0.7 ; 9.3]$ & 63 & $2.2[0.2 ; 8.1]$ & 17 & $4.9[3.8 ; 5.8]$ \\
\hline Male & 1 & $9.3[\mathrm{n} / \mathrm{a}]$ & 9 & $4.1[1.2 ; 5.4]$ & 4 & $4.9[4.6 ; 5.1]$ \\
\hline Female & 0 & $\mathrm{n} / \mathrm{a}$ & 18 & $1.8[0.8 ; 5.5]$ & 4 & $5.1[4.5 ; 5.8]$ \\
\hline Mixed & 8 & $1.0[0.7 ; 1.9]$ & 36 & $2.4[0.2 ; 8.1]$ & 9 & $4.9[3.8 ; 5.5]$ \\
\hline $\begin{array}{l}\text { All eight } \\
\text { isomers } \\
\text { together }\end{array}$ & & & & & & \\
\hline All & 408 & $10.2[1.1 ; 134.2]$ & 54 & $22.1[4.3 ; 49.0]$ & 10 & $22.6[17.1 ; 39.1]$ \\
\hline Male & 155 & $12.4[4.7 ; 48.2]$ & 6 & $23.7[18.2 ; 32.3]$ & 4 & $22.0[17.7 ; 39.1]$ \\
\hline Female & 178 & $9.9[4.6 ; 134.2]$ & 11 & $26.0[11.0 ; 49.0]$ & 4 & $23.3[17.1 ; 38.7]$ \\
\hline Mixed & 75 & $8.8[1.1 ; 63.1]$ & 37 & $18.0[4.3 ; 41.3]$ & 2 & $20.5[17.4 ; 23.5]$ \\
\hline
\end{tabular}

\section{Intake by region and country}

The majority of reported mean or median intakes of $\alpha$-tocopherol and all eight isomers together were below recommended intake values in all the countries and regions included in this global review (Figure 2). Applying an RDA of $15 \mathrm{mg} / \mathrm{day}$ and an EAR of $12 \mathrm{mg} /$ day globally to all populations with a minimum age of 14 years [1], 82 and $61 \%$ of all subentries are below the RDA and the EAR, respectively. In the Americas, $91 \%$ of all subentries are below the RDA and $89 \%$ below the EAR. We find 80 and $55 \%$ of the subentries in Europe below the RDA and the EAR, respectively. The corresponding proportions in Asia Pacific are $79 \%$ below the RDA and $68 \%$ below the EAR. Even using the more conservative approach proposed by the WHO (10 $\mathrm{mg} /$ day intake), we find $83 \%$ of the subentries in the Americas, $35 \%$ of the subentries in Europe, and $60 \%$ of the subentries in Asia Pacific below this intake level. However, the reported low intake levels in different countries do not necessarily reflect the serum concentrations in these countries.

\section{Serum concentrations by region and country}

Figure 3 depicts serum concentrations of $\alpha$-tocopherol and all eight isomers together (subentries; mean or median) plotted by region and country. Globally $13 \%$ of the reported values do not reach the functional deficiency threshold concentration of $12 \mu \mathrm{mol} / \mathrm{L}$, mostly newborns and children up to the age of 12 years. In the Americas, $11 \%$ of the reported subentries are in the functional deficiency range. The highest proportion of data points in the deficiency range is found in populations in the Middle East and Africa (27\%), but values are also relatively high in Asia Pacific (16\%) and Europe ( $8 \%$ ). Considering a threshold concentration of $20 \mu \mathrm{mol} / \mathrm{L}$ recommended by some experts [14], $27 \%$ of the American, $80 \%$ of the Middle East/ African, $62 \%$ of the Asian, and $19 \%$ of the European study data points are below this serum value. The average serum $\alpha$-tocopherol concentration of 20 $\mu \mathrm{mol} / \mathrm{L}$ can be reached in normal healthy adults who consume a variety of foods, including whole grains, seeds, and nuts. On the other hand only $21 \%$ of the total data points included in this global review reach a desirable mean serum concentration of $30 \mu \mathrm{mol} / \mathrm{L}$ or higher. 


\section{Serum concentrations by age group}

In Figure 4 the serum concentrations of $\alpha$-tocopherol and all eight isomers together are shown by age group. Concentrations below the deficiency threshold of $12 \mu \mathrm{mol} / \mathrm{L}$ (as defined by the IOM for healthy adults [1] and confirmed by other authors for children [14]) were found predominantly in newborns and children up to the age of 12 years. Globally, $13 \%$ of the subentries were below $12 \mu \mathrm{mol} / \mathrm{L}$ (functional deficiency), $66 \%$ between 12 and $30 \mu \mathrm{mol} / \mathrm{L}$, and $21 \%$ above $30 \mu \mathrm{mol} / \mathrm{L}$ (desirable mean serum concentration). Within the NHANES study, a significant association was found between age and serum concentrations [80]. This trend is also reflected in the rest of the data set.

\section{Discussion}

\section{Intake}

Since only a small proportion of the studies provided both nutritional intake data and data on status measured in blood, a correlation between the two data sets was beyond the scope of this review. Moreover, possible limitations of dietary intake surveys because of e. g. underreporting should also be considered when interpreting the results [12]. The intake of $\alpha$-tocopherol and other isomers was generally low compared to the RDA recommended by the IOM and very similar across all the regions worldwide. Globally, $82 \%$ of the subentries were below $15 \mathrm{mg}$ /day intake; this value was $91 \%$ in North and South America, $79 \%$ in the AsiaPacific region, and $80 \%$ in Europe. The biggest study on intakes in the data set was the pan-European EPIC

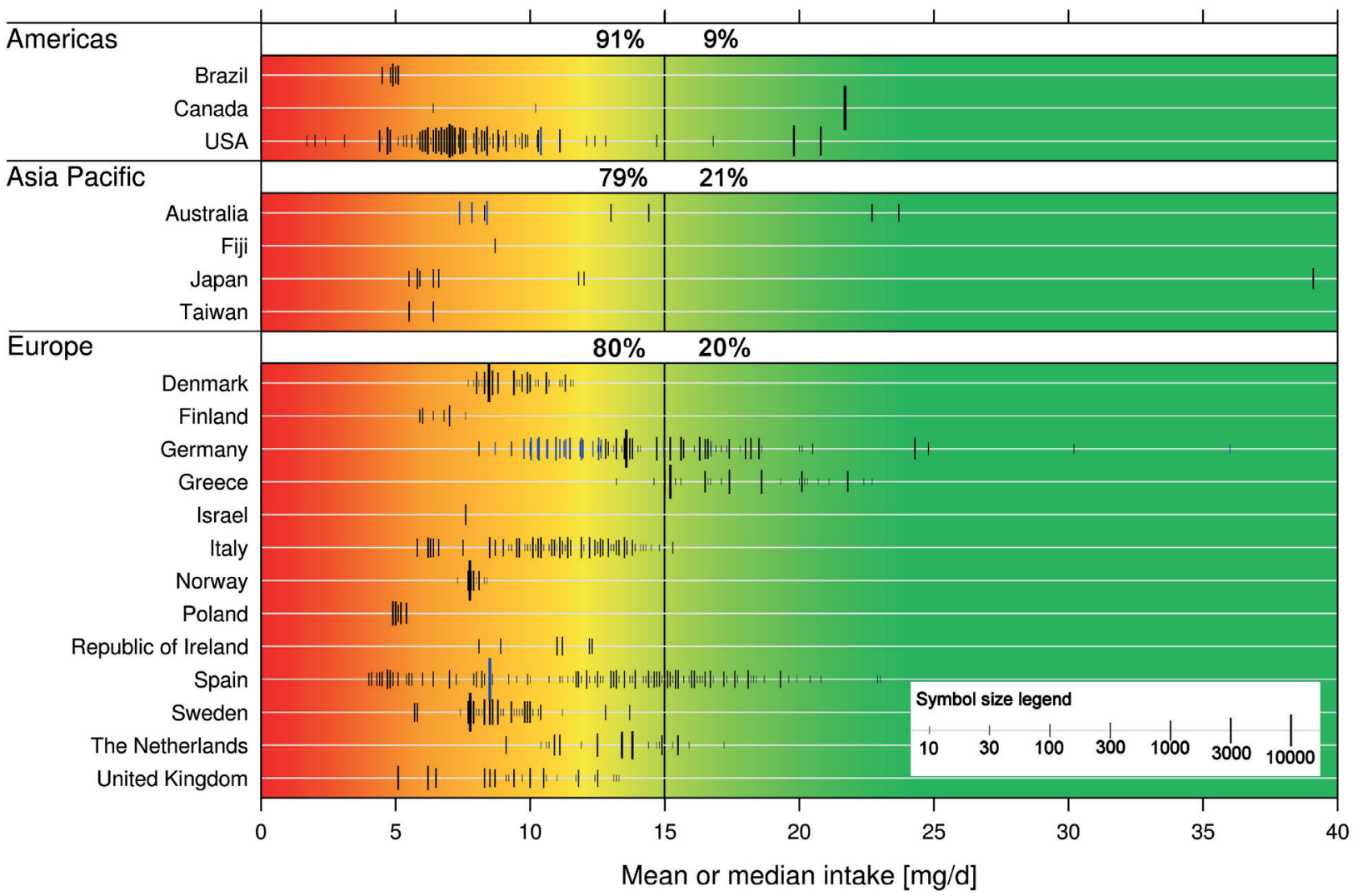

Figure 2: Vitamin E (alpha-tocopherol and all eight isomers together) intake values (in total 652 subentries; mean /black/ or median /blue/) by region and country for populations with a minimum age of 14 years. The figure shows all subentries as reported in the publications, with each symbol corresponding to one subentry. The symbol size was set to $0.3 \times \mathrm{N}^{0.2}$ for intake values, where $\mathrm{N}$ refers to the subgroup size. The vertical line indicates the RDA of $15 \mathrm{mg} / \mathrm{day}$ recommended by IOM. Globally, $82 \%$ of the subentries were below $15 \mathrm{mg} /$ day while $18 \%$ were above. For 284 subentries the subgroup size was not available, mostly for age subgroups in Jenab et al., 2009, who reported on the large pan-European EPIC study [107]. Wherever the subgroup size was not available, it was assumed to be $\mathrm{N}=5$ to obtain a small but visible symbol. Four values are not visible in the figure because they are higher than $40 \mathrm{mg} /$ day. Red: low intake ( $\leq 5 \mathrm{mg} /$ day $)$, yellow: moderate intake (6-14 mg/day), green: recommended intake or above ( $\geq 15 \mathrm{mg} /$ day $) . \mathrm{n}=128$ studies. 


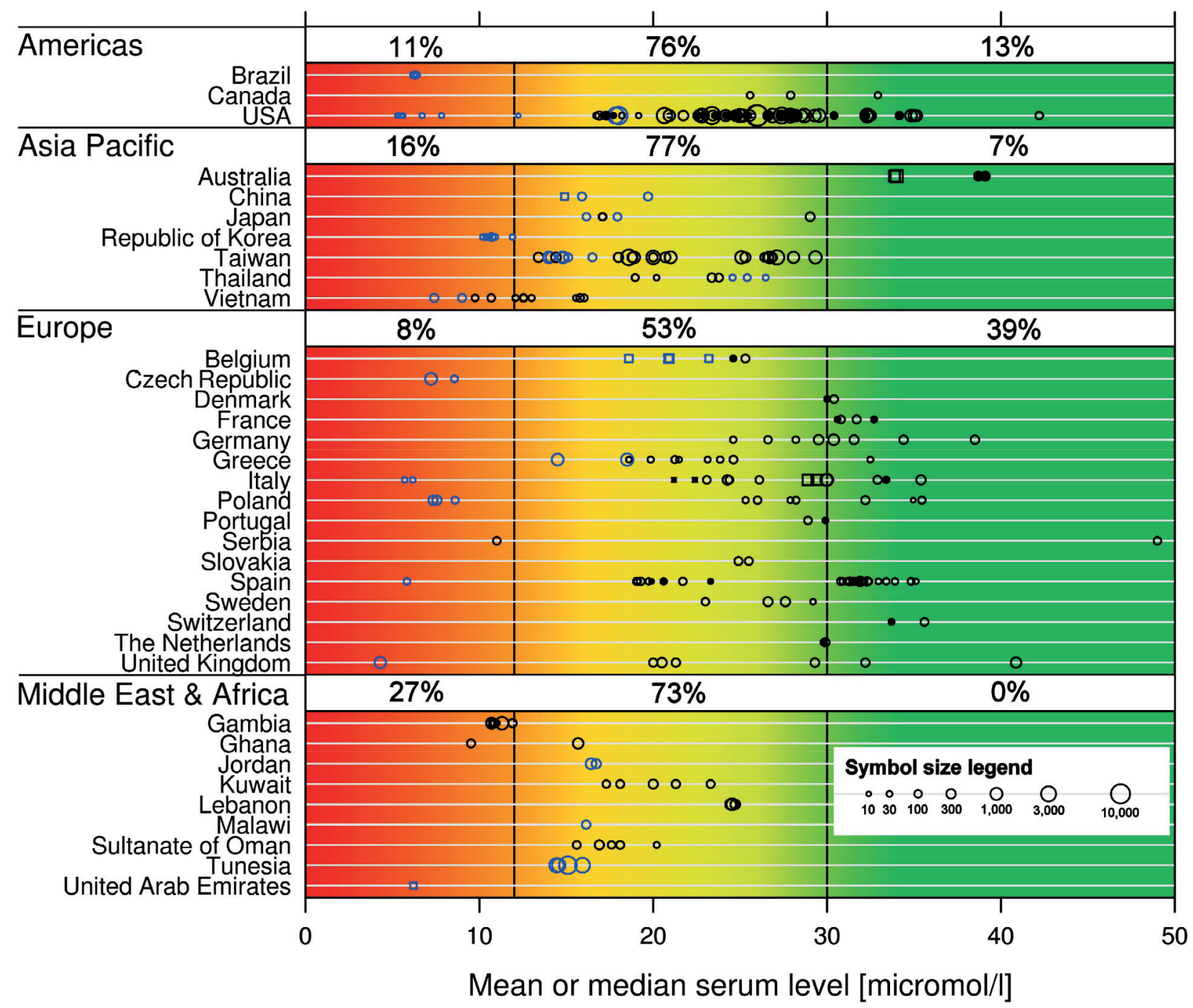

Figure 3: Vitamin E (alpha-tocopherol and all eight isomers together) serum concentrations (in total 278 subentries; mean or median) by region and country. The figure shows all subentries as reported in the publications, with each symbol corresponding to one subentry. The symbol size was set to $0.2 \times \mathrm{N}^{0.2}$ for serum values, where $\mathrm{N}$ refers to the subgroup size; $\mathrm{o}=$ unadjusted; = lipid adjusted; black = mean; $\square=$ median; blue: $0-12$ years; black: $>12$ years. The graph includes 3 data points with unclear population size (assumed to be $\mathrm{N}=5$ ), located in the US, from the Diet, Supplement, and Health Study [197, 198]. Red: concentration in functional deficiency range $(\leq 12 \mu \mathrm{mol} / \mathrm{L})$, yellow: concentration between functional deficiency and desirable threshold $(13-29 \mu \mathrm{mol} / \mathrm{L})$, green: concentration in desirable range $(\geq 30 \mu \mathrm{mol} / \mathrm{L}) . \mathrm{n}=128 \mathrm{studies}$.

study with 36,000 participants. The overall mean intake was $11.9 \mathrm{mg} /$ day. It showed an interesting regional difference: higher in the southern countries, lower in the northern ones. This may be related to the food sources, particularly vegetable oils, which are popular in the south [107]. The explanations of our findings regarding the generally low intake may be manifold. For methodological reasons, vitamin E might be underestimated and thus underreported in most of the intake assessments (e.g., misreporting food intake in the past, difficulty of portion size estimation, variability between interviewers) [12]. On the other hand, recent studies about vitamin E stability in vegetable oils suggest that the actual intakes might be even lower than estimated. Commercial vegetable oils, which contain vitamin E, are commonly stored in the supermarket or kitchen in transparent polyethylene terephthalate (PET) bottles. Light, temperature, and oxygen availability have been shown to promote rancidity in these vegetable oils. Recent studies demonstrated that storing soybean oil in transparent bottles under household conditions might pose an increased risk for accelerated lipid oxidation [206]. Therefore, the oxidative stability of vitamin $\mathrm{E}$ in edible oils is limited and vegetable 


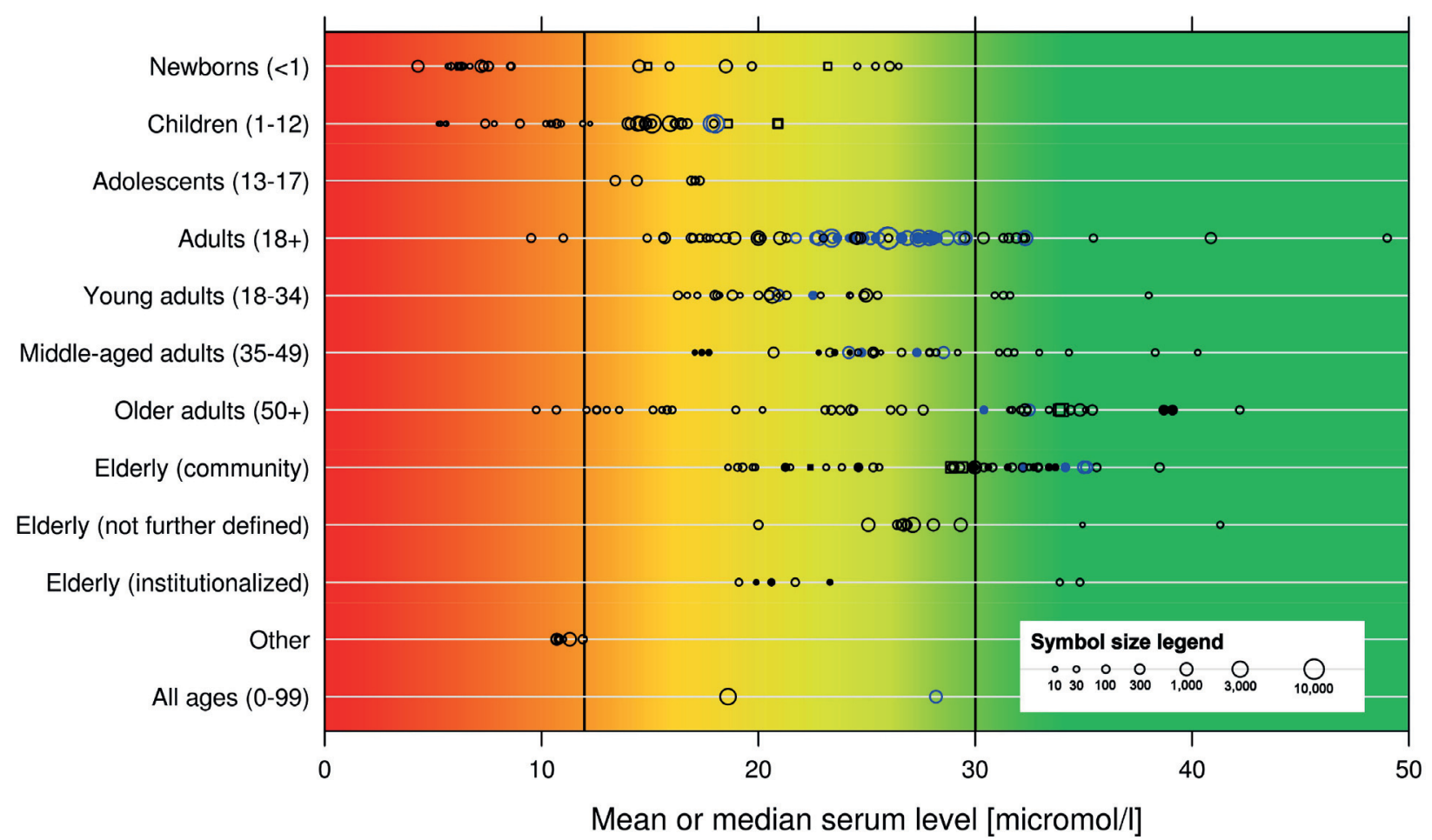

Figure 4: Vitamin E (alpha-tocopherol and all eight isomers together) serum concentrations (subentries; mean or median) by age group. The figure shows all subentries as reported in the publications, with each symbol corresponding to one subentry. The symbol size was set to $0.2 \times \mathrm{N}^{0.2}$ for serum values, where $\mathrm{N}$ refers to the subgroup size; $\mathrm{o}=$ unadjusted; = lipid-adjusted; black $=$ mean; $\square=$ median; blue $=$ NHANES data; other $=$ not specified. Red: concentration in functional deficiency range $(\leq 12 \mu \mathrm{mol} / \mathrm{L})$, yellow: concentration between functional deficiency and desirable threshold $(13-29 \mu \mathrm{mol} / \mathrm{L})$, green: concentration in desirable range $(\geq 30 \mu \mathrm{mol} / \mathrm{L}) \cdot \mathrm{n}=132$ studies.

oils might contribute less to vitamin E intake than has been thought so far.

\section{Serum concentrations}

The few existing reviews on this topic report substantial variations in the prevalence of vitamin E deficiency across countries worldwide, with estimates ranging from 0.7 to $89.0 \%$ depending on cut-off value and study population [207, 208]. By using a systematic approach, this review is the first to provide a detailed description of the existing data on vitamin E status worldwide, including developed and developing countries.

In our evaluation, $13 \%$ of the subentries in the global data set were below the deficiency threshold of $12 \mu \mathrm{mol} / \mathrm{L}$ defined by the IOM [1]. The most affected age groups were newborns and children, who frequently had serum concentrations below $12 \mu \mathrm{mol} / \mathrm{L}$. We also observed a steady and age-dependent increase of the serum concentrations, which can be explained by the higher circulating lipid concentrations in the older age groups.
The largest study on serum concentrations in the data set is the NHANES, which is also the study with the most publications $(\mathrm{n}=13)$ in our data set. Ford et al. [2006] provided details about the statistically significant age gradient within the NHANES $(\mathrm{p}<0.001)$, which is in agreement with our global data set. The older the subjects, the higher the $\alpha$-tocopherol concentration, even if adjusted for cholesterol [80]. In our review, globally $66 \%$ of all subentries range between 12 and $30 \mu \mathrm{mol} / \mathrm{L}$. Only $21 \%$ of them meet the proposed desirable concentration of $\geq 30 \mu \mathrm{mol} / \mathrm{L}$, at which beneficial health effects may occur.

However, interpretation of the measured $\alpha$-tocopherol values is challenging due to the positive correlation with different blood lipids. Various methods to control the confounding effect of blood lipids have been suggested in the literature, but they are not completely effective [209]. The data are very heterogeneous; even within one country we observed values ranging from about 5 to $35 \mu \mathrm{mol} / \mathrm{L}$. In the total data set we observed a significant difference between the adjusted and unadjusted serum concentrations. However, the difference between the adjusted and unadjusted serum concentrations disappeared in our 
data set once age group was included as a covariate ( $\mathrm{p}=0.63$; data not shown). The previous difference was again mainly driven by newborns and children, who tend to have lower serum concentrations than adults [210]. Nevertheless, more research is needed to clarify and verify the biological relevance of the $\alpha$-tocopherol serum range between 12 and $30 \mu \mathrm{mol} / \mathrm{L}$ in both adults and children. More accurate understanding of the relationship of vitamin E dosage to the level of protection is required. Biomarkers are needed to be used in the assessment of vitamin E intake and status. Largescale studies in children have to be conducted using such validated biomarkers to assess their vitamin $\mathrm{E}$ requirements. More information is needed also on the other isoforms of vitamin E. By establishing the recommended $\alpha$-tocopherol intake levels and reference serum concentrations, the functions and concentrations of the other tocopherol forms that can have antagonistic effects to that of $\alpha$-tocopherol were not considered. Thus, much needs to be done to study what minimal concentrations are beneficial in the presence of other competing isoforms of tocopherols.

\section{Strengths and limitations}

To our knowledge, this systematic review, which was conducted in accordance with the PRISMA statement [25], is the first to focus on the worldwide published scientific literature reporting vitamin E dietary intake levels and serum concentrations. We purposefully identified studies with randomly selected persons from the general population living in both developing and developed countries. Special population groups (e.g., patients, subjects of clinical trials) were excluded.

It is important to consider the findings of this review in the context of potential limitations. All subentries were considered as reported in the publications (median, mean, or geometric mean), which provides a comprehensive picture and captures heterogeneity among subgroups but may also lead to under- or overrepresentation of some studies. Many studies report results according to several predictors. In Ford et al., 2006, for example, the serum concentrations of NHANES are differentiated by gender, age group, and race [80]. In contrast, the EPIC study focused on intake levels instead of serum concentrations. These intake levels are differentiated by country, gender, and age categories that differ from those of NHANES, whereas race is not differentiated [107]. We accepted this redundancy and the differences in reporting among studies for the sake of completeness. An alternative might have been to condense each study into a single value.
However, this would have introduced a selection bias and provided an artificial sense of uniformity because it would have masked the considerable differences among population subgroups within a study, notably among age groups. Also, for the sake of completeness, no distinction has been made between representative and non-representative studies. Furthermore, no consideration could be given to the quality of the dietary assessment data, or to the standardization of blood assays in different studies.

Because only a small proportion of the obtained serum concentration data was lipid-adjusted, we conducted no statistical evaluations on this subset. Another factor that could influence the interpretation of data is that supplement use was not sufficiently reported in half of the studies. Furthermore, we limited ourselves to mostly descriptive data analysis due to the considerable heterogeneity of the data.

\section{Conclusions}

This comprehensive review of vitamin E dietary intake levels and serum concentrations demonstrates that the majority of reported intake values worldwide are below the recommended level. Similarly, it shows that a considerable proportion of the data points of the global population do not reach the functional deficiency threshold serum concentration for $\alpha$-tocopherol, particularly in newborns and children. Probably due to language bias, we observe a geographical knowledge gap for Latin America, the Middle East and Africa, and Asia Pacific. While there is still no consensus among scientists regarding desirable $\alpha$-tocopherol serum concentrations, our results based on the reported dietary intake levels and serum concentrations suggest that the vitamin E status of the included population groups can be improved. Possible measures include encouragement of consumption of vitamin E-rich food sources (e.g. vegetables, dairy products, eggs), adequate fortification of food products (e.g. vegetable oils), and supplementation. This systematic review could be a useful stepping stone for researchers to combine existing data, fill in data gaps, and to understand more about the complex field of vitamin $\mathrm{E}$ and its impact on human health.

\section{Acknowledgments}

Kristina Hoffmann and Peter Weber share senior authorship. 
SP, AF, FR, AW, ME, KH, and PW designed the project; SP coordinated the project; AF reviewed the literature; FR analyzed and visualized data; SP, AF, FR, AW, ME, KH, and PW wrote the paper; $\mathrm{KH}$ and PW had primary responsibility for the final contents. All authors read and approved the final manuscript. The authors thank Tatiana Görig from the Mannheim Institute of Public Health for reviewing the literature and Susan Sills for language editing. The Mannheim Institute of Public Health, Social and Preventive Medicine received an unrestricted educational grant from DSM Nutritional Products Ltd.

\section{Conflicts of interest}

Szabolcs Péter, Angelika Friedel, Franz F. Roos, Adrian Wyss, Manfred Eggersdorfer, and Peter Weber are employees of DSM Nutritional Products Ltd. The Mannheim Institute of Public Health, Social and Preventive Medicine received an unrestricted educational grant from DSM Nutritional Products Ltd.

\section{References}

1. IOM. (2000) Vitamin E. In: Dietary Reference Intakes for Vitamin C, Vitamin E, Selenium, and Carotenoids. pp. 186-283, National Academies Press (US), Washington DC.

2. Peter, S., Moser, U., Pilz, S., Eggersdorfer, M. and Weber, P. (2013) The challenge of setting appropriate intake recommendations for vitamin $\mathrm{E}$ : considerations on status and functionality to define nutrient requirements. Int $\mathrm{J}$ Vitam Nutr Res. 83, 129-136.

3. Zhang, X., Feng, M., Liu, F., Qin, L., Qu, R., Li, D. and Wang, Z. (2014) Subacute oral toxicity of BDE-15, CDE-15, and HODE-15 in ICR male mice: assessing effects on hepatic oxidative stress and metals status and ascertaining the protective role of vitamin E. Environ Sci Pollut Res Int. 21, 1924-1935.

4. Boda, V., Finckh, B., Durken, M., Commentz, J., Hellwege, H.H. and Kohlschutter, A. (1998) Monitoring erythrocyte free radical resistance in neonatal blood microsamples using a peroxyl radicalmediated haemolysis test. Scand J Clin Lab Invest. 58, $317-322$.

5. Sokol, R.J., Kayden, H.J., Bettis, D.B., Traber, M.G., Neville, H., Ringel, S., Wilson, W.B. and Stumpf, D.A. (1988) Isolated vitamin E deficiency in the absence of fat malabsorption-familial and sporadic cases: characterization and investigation of causes. $\mathrm{J}$ Lab Clin Med. 111, 548-559.

6. EFSA (2011) Scientific Opinion on the substantiation of health claims related to vitamin $E$ and protection of DNA, proteins and lipids from oxidative damage (ID $160,162,1947)$, maintenance of the normal function of the immune system (ID 161, 163), maintenance of normal bone (ID 164), maintenance of normal teeth (ID 164), maintenance of normal hair (ID 164), maintenance of normal skin (ID 164), maintenance of normal nails (ID 164), maintenance of normal cardiac function (ID 166), maintenance of normal vision by protection of the lens of the eye (ID 167), contribution to normal cognitive function (ID 182, 183), regeneration of the reduced form of vitamin C (ID 203), maintenance of normal blood circulation (ID 216) and maintenance of normal a scalp (ID 2873) pursuant to Article 13(1) of Regulation (EC) No 1924/2006. EFSA J. 9, 2077. http://www.efsa. europa.eu/en/efsajournal/pub/1816.htm

7. Horwitt, M.K., Harvey, C.C., Duncan, G.D. and Wilson, W.C. (1956) Effects of limited tocopherol intake in man with relationships to erythrocyte hemolysis and lipid oxidations. Am J Clin Nutr. 4, 408-419.

8. Horwitt, M.K. (1960) Vitamin E and lipid metabolism in man. Am J Clin Nutr. 8, 451-461.

9. Horwitt, M.K., Century, B. and Zeman, A.A. (1963) Erythrocyte survival time and reticulocyte levels after tocopherol depletion in man. Am J Clin Nutr. 12, 99-106.

10. Fulgoni, V.L., 3rd, Keast, D.R., Bailey, R.L. and Dwyer, J. (2011) Foods, fortificants, and supplements: Where do Americans get their nutrients? J Nutr. 141, 1847-1854.

11. Troesch, B., Hoeft, B., McBurney, M., Eggersdorfer, M. and Weber, P. (2012) Dietary surveys indicate vitamin intakes below recommendations are common in representative Western countries. Br J Nutr. 108, 692-698.

12. Gemming, L., Jiang, Y., Swinburn, B., Utter, J. and Mhurchu, C.N. (2014) Under-reporting remains a key limitation of self-reported dietary intake: an analysis of the 2008/09 New Zealand Adult Nutrition Survey. Eur J Clin Nutr. 68, 259-264.

13. Mangialasche, F., Xu, W., Kivipelto, M., Costanzi, E., Ercolani, S., Pigliautile, M., Cecchetti, R., Baglioni, M., Simmons, A., Soininen, H., Tsolaki, M., Kloszewska, I., Vellas, B., Lovestone, S., Mecocci, P. and AddNeuroMed Consortium (2012) Tocopherols and tocotrienols plasma levels are associated with cognitive impairment. Neurobiol Aging. 33, 2282-2290. 
14. Traber, M.G. (2014) Vitamin E inadequacy in humans: causes and consequences. Adv Nutr. 5, 503-514.

15. Gey, K.F. (1995) Cardiovascular disease and vitamins. Concurrent correction of 'suboptimal' plasma antioxidant levels may, as important part of 'optimal' nutrition, help to prevent early stages of cardiovascular disease and cancer, respectively. Bibl Nutr Dieta. 52, 75-91.

16. Gey, K.F. (1993) Prospects for the prevention of free radical disease, regarding cancer and cardiovascular disease. Br Med Bull. 49, 679-699.

17. Biesalski, H.K., Bohles, H., Esterbauer, H., Furst, P., Gey, F., Hundsdorfer, G., Kasper, H., Sies, H. and Weisburger, J. (1997) Antioxidant vitamins in prevention. Clin Nutr. 16, 151-155.

18. Wright, M.E., Lawson, K.A., Weinstein, S.J., Pietinen, P., Taylor, P.R., Virtamo, J. and Albanes, D. (2006) Higher baseline serum concentrations of vitamin $\mathrm{E}$ are associated with lower total and cause-specific mortality in the Alpha-Tocopherol, Beta-Carotene Cancer Prevention Study. Am J Clin Nutr. 84, 1200-1207.

19. Weinstein, S.J., Wright, M.E., Lawson, K.A., Snyder, K., Mannisto, S., Taylor, P.R., Virtamo, J. and Albanes, D. (2007) Serum and dietary vitamin E in relation to prostate cancer risk. Cancer Epidemiol Biomarkers Prev. 16, 1253-1259.

20. Goyal, A., Terry, M.B. and Siegel, A.B. (2013) Serum antioxidant nutrients, vitamin $\mathrm{A}$, and mortality in U.S. Adults. Cancer Epidemiol Biomarkers Prev. 22, $2202-2211$.

21. Lebold, K.M., Ang, A., Traber, M.G. and Arab, L. (2012) Urinary alpha-carboxyethyl hydroxychroman can be used as a predictor of alpha-tocopherol adequacy, as demonstrated in the Energetics Study. Am J Clin Nutr. 96, 801-809.

22. Lemoyne, M., Van Gossum, A., Kurian, R., Ostro, M., Axler, J. and Jeejeebhoy, K.N. (1987) Breath pentane analysis as an index of lipid peroxidation: a functional test of vitamin E status. Am J Clin Nutr. 46, 267-272.

23. Deutsche Gesellschaft für Ernährung, Ö.G.f.E., Schweizerische GesellschaftfürErnährungsforschung, Schweizerische Vereinigung für Ernährung. (2008) Referenzwerte für die Nährstoffzufuhr, Neustadt/ Weinstraße.

24. WHO. (2003) Diet, nutrition and the prevention of chronic diseases. World Health Organ Tech Rep Ser. 916, 1-149.

25. Moher, D., Liberati, A., Tetzlaff, J., Altman, D.G.; PRISMA Group (2010) Preferred reporting items for systematic reviews and meta-analyses: the PRISMA statement. Int J Surg. 8, 336-341.
26. Behrens, W.A. and Madere, R. (1986) Alpha- and gamma tocopherol concentrations in human serum. $\mathrm{J}$ Am Coll Nutr. 5, 91-96.

27. Handelman, G.J., Machlin, L.J., Fitch, K., Weiter, J.J. and Dratz, E.A. (1985) Oral alpha-tocopherol supplements decrease plasma gamma-tocopherol levels in humans. J Nutr. 115, 807-813.

28. Handelman, G.J.,Epstein, W.L., Peerson, J., Spiegelman, D., Machlin, L.J. and Dratz, E.A. (1994) Human adipose alpha-tocopherol and gamma-tocopherol kinetics during and after $1 \mathrm{y}$ of alpha-tocopherol supplementation. Am J Clin Nutr. 59, 1025-1032.

29. RCT (2012) A language and environment for statistical computing, R Foundation for Statistical Computing, Vienna, Austria.

30. Abiaka, C., Al-Tobi, M. and Joshi, R. (2008) Serum micronutrient and micromineral concentrations and ratios in healthy Omani subjects. Med Princ Pract. 17, 334-339.

31. Abiaka, C., Olusi, S. and Simbeye, A. (2002) Serum concentrations of micronutrient antioxidants in an adult Arab population. Asia Pac J Clin Nutr. 11, $22-27$.

32. Agudo, A., Cabrera, L., Amiano, P., Ardanaz, E., Barricarte, A., Berenguer, T., Chirlaque, M.D., Dorronsoro, M., Jakszyn, P., Larranaga, N., Martinez, C., Navarro, C., Quiros, J.R., Sanchez, M.J., Tormo, M.J. and Gonzalez, C.A. (2007) Fruit and vegetable intakes, dietary antioxidant nutrients, and total mortality in Spanish adults: findings from the Spanish cohort of the European Prospective Investigation into Cancer and Nutrition (EPIC-Spain). Am J Clin Nutr. 85, 1634-1642.

33. Alencar, L.E., Martinez, A., Fernandez, C., Garaulet, M., Perez-Llamas, F. and Zamora, S. (2000) Dietary intake in adolescents from south-east Spain and its relationship with physical activity. Nutr Hosp. 15, $51-57$.

34. Amirlak, I., Ezimokhai, M., Dawodu, A., Dawson, K.P., Kochiyil, J., Thomas, L. and Abdulle, A.M. (2009) Current maternal-infant micronutrient status and the effects on birth weight in the United Arab Emirates. East Mediterr Health J. 15, 1399-1406.

35. Anderson, J.J., Suchindran, C.M. and Roggenkamp, K.J. (2009) Micronutrient intakes in two US populations of older adults: lipid research clinics program prevalence study findings. J Nutr Health Aging. 13, 595-600.

36. Arab, L., Carriquiry, A., Steck-Scott, S. and Gaudet, M.M. (2003) Ethnic differences in the nutrient intake adequacy of premenopausal US women: results from the Third National Health Examination Survey. J Am Diet Assoc. 103, 1008-1014. 
37. Arnlov, J., Zethelius, B., Riserus, U., Basu, S., Berne, C., Vessby, B., Alfthan, G., Helmersson, J. and Uppsala Longitudinal Study of Adult Men Study (2009) Serum and dietary beta-carotene and alpha-tocopherol and incidence of type 2 diabetes mellitus in a communitybased study of Swedish men: report from the Uppsala Longitudinal Study of Adult Men (ULSAM) study. Diabetologia. 52, 97-105.

38. Azzini, E., Polito, A., Fumagalli, A., Intorre, F., Venneria, E., Durazzo, A., Zaccaria, M., Ciarapica, D., Foddai, M.S., Mauro, B., Raguzzini, A., Palomba, L. and Maiani, G. (2011) Mediterranean Diet Effect: an Italian picture. Nutr J. 10, 125.

39. Balkan, J., Dogru-Abbasoglu, S., Aykac-Toker, G. and Uysal, M. (2004) Serum pro-oxidant-antioxidant balance and low-density lipoprotein oxidation in healthy subjects with different cholesterol levels. Clin Exp Med. 3, 237-242.

40. Balkan, J., Kanbagli, O., Mehmetcik, G., MutluTurkoglu, U., Aykac-Toker, G. and Uysal, M. (2002) Increased lipid peroxidation in serum and low-density lipoproteins associated with aging in humans. Int $\mathbf{J}$ Vitam Nutr Res. 72, 315-320.

41. Barros, M.F., Leger, C.L., Lira, P.I., Lima, M.C., Carbonneau, M.A., Descomps, B. and Alessio, M.L. (2002) Cord blood essential fatty acid and alphatocopherol in full-term newborns in a Northeast Brazil area. Int J Vitam Nutr Res. 72, 155-160.

42. Bartali, B., Frongillo, E.A., Guralnik, J.M., Stipanuk, M.H., Allore, H.G., Cherubini, A., Bandinelli, S., Ferrucci, L. and Gill, T.M. (2008) Serum micronutrient concentrations and decline in physical function among older persons. JAMA. 299, 308-315.

43. Bas, M., Altan, T., Dincer, D., Aran, E., Kaya, H.G. and Yuksek, O. (2005) Determination of dietary habits as a risk factor of cardiovascular heart disease in Turkish adolescents. Eur J Nutr. 44, 174-182.

44. Bates, C.J., Matthews, N., West, B., Morison, L. and Walraven, G. (2002) Plasma carotenoid and vitamin E concentrations in women living in a rural west African (Gambian) community. Int J Vitam Nutr Res. 72, 133-141.

45. Beitz, R., Mensink, G.B., Fischer, B. and Thamm, M. (2002) Vitamins - dietary intake and intake from dietary supplements in Germany. Eur J Clin Nutr. 56, $539-545$.

46. Beitz, R., Mensink, G.B., Henschel, Y., Fischer, B. and Erbersdobler, H.F. (2004) Dietary behaviour of German adults differing in levels of sport activity. Public Health Nutr. 7, 45-52.

47. Belanger, M.C., Mirault, M.E., Dewailly, E., Berthiaume, L. and Julien, P. (2008) Environmental contaminants and redox status of coenzyme Q10 and vitamin $\mathrm{E}$ in Inuit from Nunavik. Metabolism. 57, 927-933.

48. Beydoun, M.A., Shroff, M.R., Chen, X., Beydoun, H.A., Wang, Y. and Zonderman, A.B. (2011) Serum antioxidant status is associated with metabolic syndrome among U.S. adults in recent national surveys. J Nutr. 141, 903-913.

49. Bianchini, F., Elmstahl, S., Martinez-Garcia, C., van Kappel, A.L., Douki, T., Cadet, J., Ohshima, H., Riboli, E. and Kaaks, R. (2000) Oxidative DNA damage in human lymphocytes: correlations with plasma levels of alpha-tocopherol and carotenoids. Carcinogenesis. 21, 321-324.

50. Ble, A., Cherubini, A., Volpato, S., Bartali, B., Walston, J.D., Windham, B.G., Bandinelli, S., Lauretani, F., Guralnik, J.M. and Ferrucci, L. (2006) Lower plasma vitamin E levels are associated with the frailty syndrome: the InCHIANTI study. J Gerontol A Biol Sci Med Sci. 61, 278-283.

51. Boeing, H., Weisgerber, U.M., Jeckel, A., Rose, H.J. and Kroke, A. (2000) Association between glycated hemoglobin and diet and other lifestyle factors in a nondiabetic population: cross-sectional evaluation of data from the Potsdam cohort of the European Prospective Investigation into Cancer and Nutrition Study. Am J Clin Nutr. 71, 1115-1122.

52. Breilmann, J., Pons-Kuhnemann, J., Brunner, C., Richter, M. and Neuhauser-Berthold, M. (2010) Effect of antioxidant vitamins on the plasma homocysteine level in a free-living elderly population. Ann Nutr Metab. 57, 177-182.

53. Briefel, R., Hanson, C., Fox, M.K., Novak, T. and Ziegler, P. (2006) Feeding Infants and Toddlers Study: do vitamin and mineral supplements contribute to nutrient adequacy or excess among US infants and toddlers? J Am Diet Assoc. 106, S52-65.

54. Briefel, R., Ziegler, P., Novak, T. and Ponza, M. (2006) Feeding Infants and Toddlers Study: characteristics and usual nutrient intake of Hispanic and non-Hispanic infants and toddlers. J Am Diet Assoc. 106, S84-95.

55. Buijsse, B., Feskens, E.J., Kwape, L., Kok, F.J. and Kromhout, D. (2008) Both alpha- and beta-carotene, but not tocopherols and vitamin $\mathrm{C}$, are inversely related to 15 -year cardiovascular mortality in Dutch elderly men. J Nutr. 138, 344-350.

56. Buijsse, B., Feskens, E.J., Schlettwein-Gsell, D., Ferry, M., Kok, F.J., Kromhout, D. and de Groot, L.C. (2005) Plasma carotene and alpha-tocopherol in relation to 10-y all-cause and cause-specific mortality in European elderly: the Survey in Europe on Nutrition and the Elderly, a Concerted Action (SENECA). Am J Clin Nutr. 82, 879-886. 
57. Butland, B.K., Fehily, A.M. and Elwood, P.C. (2000) Diet, lung function, and lung function decline in a cohort of 2512 middle aged men. Thorax. 55, 102-108.

58. Butte, N.F., Fox, M.K., Briefel, R.R., Siega-Riz, A.M., Dwyer, J.T., Deming, D.M. and Reidy, K.C. (2010) Nutrient intakes of US infants, toddlers, and preschoolers meet or exceed dietary reference intakes. J Am Diet Assoc. 110, S27-S37.

59. Camoes, M. and Lopes, C. (2008) Dietary intake and different types of physical activity: full-day energy expenditure, occupational and leisure-time. Public Health Nutr. 11, 841-848.

60. Cesari, M., Pahor, M., Bartali, B., Cherubini, A., Penninx, B.W., Williams, G.R., Atkinson, H., Martin, A., Guralnik, J.M. and Ferrucci, L. (2004) Antioxidants and physical performance in elderly persons: the Invecchiare in Chianti (InCHIANTI) study. Am J Clin Nutr. 79, 289-294.

61. Chelchowska, M., Ambroszkiewicz, J., Gajewska, J., Laskowska-Klita, T. and Leibschang, J. (2011) The effect of tobacco smoking during pregnancy on plasma oxidant and antioxidant status in mother and newborn. Eur J Obstet Gynecol Reprod Biol. 155, $132-136$

62. Chen, K., Zhang, X., Wei, X.P., Qu, P., Liu, Y.X. and Li, T.Y. (2009) Antioxidant vitamin status during pregnancy in relation to cognitive development in the first two years of life. Early Hum Dev. 85, 421-427.

63. Cheng, W.Y., Fu, M.L., Wen, L.J., Chen, C., Pan, W.H. and Huang, C.J. (2005) Plasma retinol and a-tocopherol status of the Taiwanese elderly population. Asia Pac J Clin Nutr. 14, 256-262.

64. Cherubini, A., Martin, A., Andres-Lacueva, C., Di Iorio, A., Lamponi, M., Mecocci, P., Bartali, B., Corsi, A., Senin, U. and Ferrucci, L. (2005) Vitamin E levels, cognitive impairment and dementia in older persons: the InCHIANTI study. Neurobiol Aging. 26, 987-994.

65. Chun, O.K.,Floegel,A., Chung, S.J., Chung, C.E.,Song, W.O. and Koo, S.I. (2010) Estimation of antioxidant intakes from diet and supplements in U.S. adults. J Nutr. 140, 317-324.

66. Dancheck, B., Nussenblatt, V., Kumwenda, N., Lema, V., Neville, M.C., Broadhead, R., Taha, T.E., Ricks, M.O. and Semba, R.D. (2005) Status of carotenoids, vitamin $\mathrm{A}$, and vitamin $\mathrm{E}$ in the mother-infant dyad and anthropometric status of infants in Malawi. J Health Popul Nutr. 23, 343-350.

67. Daryani, A., Basu, S., Becker, W., Larsson, A. and Riserus, U. (2007) Antioxidant intake, oxidative stress and inflammation among immigrant women from the Middle East living in Sweden: associations with cardiovascular risk factors. Nutr Metab Cardiovasc Dis. $17,748-756$
68. de Oliveira Otto, M.C., Alonso, A., Lee, D.H., Delclos, G.L., Bertoni, A.G., Jiang, R., Lima, J.A., Symanski, E., Jacobs, D.R., Jr. and Nettleton, J.A. (2012) Dietary intakes of zinc and heme iron from red meat, but not from other sources, are associated with greater risk of metabolic syndrome and cardiovascular disease. J Nutr. 142, 526-533.

69. Dejmek, J., Ginter, E., Solansky, I., Podrazilova, K., Stavkova, Z., Benes, I. and Sram, R.J. (2002) Vitamin C, E and A levels in maternal and fetal blood for Czech and Gypsy ethnic groups in the Czech Republic. Int J Vitam Nutr Res. 72, 183-190.

70. Devaney, B., Ziegler, P., Pac, S., Karwe, V. and Barr, S.I. (2004) Nutrient intakes of infants and toddlers. J Am Diet Assoc. 104, s14-21.

71. Didenco, S., Gillingham, M.B., Go, M.D., Leonard, S.W., Traber, M.G. and McEvoy, C.T. (2011) Increased vitamin $\mathrm{E}$ intake is associated with higher alphatocopherol concentration in the maternal circulation but higher alpha-carboxyethyl hydroxychroman concentration in the fetal circulation. Am J Clin Nutr. 93, 368-373.

72. Drewel, B.T., Giraud, D.W., Davy, S.R. and Driskell, J.A. (2006) Less than adequate vitamin E status observed in a group of preschool boys and girls living in the United States. J Nutr Biochem. 17, 132-138.

73. Engelhart, M.J., Geerlings, M.I., Ruitenberg, A., van Swieten, J.C., Hofman, A., Witteman, J.C. and Breteler, M.M. (2002) Dietary intake of antioxidants and risk of Alzheimer disease. JAMA. 287, 3223-3229.

74. Erinosho, T., Dixon, L.B., Young, C., Brotman, L.M. and Hayman, L.L. (2011) Nutrition practices and children's dietary intakes at 40 child-care centers in New York City. J Am Diet Assoc. 111, 1391-1397.

75. Fares, S., Chahed, M.K., Feki, M., Beji, C., Traissac, P., El Ati, J. and Kaabachi, N. (2011) Status of vitamins $\mathrm{A}$ and $\mathrm{E}$ in schoolchildren in the centre west of Tunisia: a population-based study. Public Health Nutr. 14, 255-260

76. Farmer, B., Larson, B.T., Fulgoni, V.L., 3rd, Rainville, A.J. and Liepa, G.U. (2011) A vegetarian dietary pattern as a nutrient-dense approach to weight management: an analysis of the national health and nutrition examination survey 1999-2004. J Am Diet Assoc. 111, 819-827.

77. Fogarty, A., Lewis, S., Weiss, S. and Britton, J. (2000) Dietary vitamin E, IgE concentrations, and atopy. Lancet. 356, 1573-1574.

78. Foksinski, M., Gackowski, D., Rozalski, R., Siomek, A., Guz, J., Szpila, A., Dziaman, T. and Olinski, R. (2007) Effects of basal level of antioxidants on oxidative DNA damage in humans. Eur J Nutr. 46, 174-180. 
79. Ford, E.S., Mokdad, A.H., Ajani, U.A. and Liu, S. (2005) Associations between concentrations of alpha- and gamma-tocopherol and concentrations of glucose, glycosylated haemoglobin, insulin and C-peptide among US adults. Br J Nutr. 93, 249-255.

80. Ford, E.S., Schleicher, R.L., Mokdad, A.H., Ajani, U.A. and Liu, S. (2006) Distribution of serum concentrations of alpha-tocopherol and gamma-tocopherol in the US population. Am J Clin Nutr. 84, 375-383.

81. Gabriel, H.E., Liu, Z., Crott, J.W., Choi, S.W., Song, B.C., Mason, J.B. and Johnson, E.J. (2006) A comparison of carotenoids, retinoids, and tocopherols in the serum and buccal mucosa of chronic cigarette smokers versus nonsmokers. Cancer Epidemiol Biomarkers Prev. 15, 993-999.

82. Gale, C.R., Ashurst, H.E., Powers, H.J. and Martyn, C.N. (2001) Antioxidant vitamin status and carotid atherosclerosis in the elderly. Am $\mathrm{J}$ Clin Nutr. 74, $402-408$.

83. Gale, C.R., Hall, N.F., Phillips, D.I. and Martyn, C.N. (2001) Plasma antioxidant vitamins and carotenoids and age-related cataract. Ophthalmology. 108, $1992-1998$.

84. Galloway, A.T., Fiorito, L., Lee, Y. and Birch, L.L. (2005) Parental pressure, dietary patterns, and weight status among girls who are "picky eaters". J Am Diet Assoc. 105, 541-548.

85. Ganji, V., Hampl, J.S. and Betts, N.M. (2003) Race, gender- and age-specific differences in dietary micronutrient intakes of US children. Int J Food Sci Nutr. 54, 485-490.

86. Gao, X., Wilde, P.E., Lichtenstein, A.H., Bermudez, O.I. and Tucker, K.L. (2006) The maximal amount of dietary alpha-tocopherol intake in U.S. adults (NHANES 2001-2002). J Nutr. 136, 1021-1026.

87. Genkinger, J.M., Platz, E.A., Hoffman, S.C., Comstock, G.W. and Helzlsouer, K.J. (2004) Fruit, vegetable, and antioxidant intake and all-cause, cancer, and cardiovascular disease mortality in a community-dwelling population in Washington County, Maryland. Am J Epidemiol. 160, 1223-1233.

88. Gilliland, F.D., Berhane, K.T., Li, Y.F., Gauderman, W.J., McConnell, R. and Peters, J. (2003) Children's lung function and antioxidant vitamin, fruit, juice, and vegetable intake. Am J Epidemiol. 158, 576-584.

89. Giraud, D.W., Kim, Y.N., Cho, Y.O. and Driskell, J.A. (2008) Vitamin E inadequacy observed in a group of 2- to 6-year-old children living in Kwangju, Republic of Korea. Int J Vitam Nutr Res. 78, 148-155.

90. Gonzalez, C.A., Travier, N., Lujan-Barroso, L., Castellsague, X., Bosch, F.X., Roura, E., Bueno-
de-Mesquita, H.B., Palli, D., Boeing, H., Pala, V., Sacerdote, C., Tumino, R., Panico, S., Manjer, J., Dillner, J., Hallmans, G., Kjellberg, L., Sanchez, M.J., Altzibar, J.M., Barricarte, A., Navarro, C., Rodriguez, L., Allen, N., Key, T.J., Kaaks, R., Rohrmann, S., Overvad, K., Olsen, A., Tjonneland, A., Munk, C., Kjaer, S.K., Peeters, P.H., van Duijnhoven, F.J., Clavel-Chapelon, F., Boutron-Ruault, M.C., Trichopoulou, A., Benetou, V., Naska, A., Lund, E., Engeset, D., Skeie, G., Franceschi, S., Slimani, N., Rinaldi, S. and Riboli, E. (2011) Dietary factors and in situ and invasive cervical cancer risk in the European prospective investigation into cancer and nutrition study. Int J Cancer. 129, 449-459.

91. Gopinath, B., Flood, V.M., McMahon, C.M., Burlutsky, G., Spankovich, C., Hood, L.J. and Mitchell, P. (2011) Dietary antioxidant intake is associated with the prevalence but not incidence of age-related hearing loss. J Nutr Health Aging. 15, 896-900.

92. Grant, B.J., Kudalkar, D.P., Muti, P., McCann, S.E., Trevisan, M., Freudenheim, J.L. and Schunemann, H.J. (2003) Relation between lung function and $\mathrm{RBC}$ distribution width in a population-based study. Chest. 124, 494-500.

93. Gross, M., Yu, X., Hannan, P., Prouty, C. and Jacobs, D.R., Jr. (2003) Lipid standardization of serum fatsoluble antioxidant concentrations: the YALTA study. Am J Clin Nutr. 77, 458-466.

94. Helmersson, J., Arnlov, J., Larsson, A. and Basu, S. (2009) Low dietary intake of beta-carotene, alphatocopherol and ascorbic acid is associated with increased inflammatory and oxidative stress status in a Swedish cohort. Br J Nutr. 101, 1775-1782.

95. Helmersson, J., Arnlov, J., Vessby, B., Larsson, A., Alfthan, G. and Basu, S. (2005) Serum selenium predicts levels of $\mathrm{F} 2$-isoprostanes and prostaglandin F2alpha in a 27 year follow-up study of Swedish men. Free Radic Res. 39, 763-770.

96. Helmersson, J., Larsson, A., Vessby, B. and Basu, S. (2005) Active smoking and a history of smoking are associated with enhanced prostaglandin $\mathrm{F}$ (2alpha), interleukin-6 and F2-isoprostane formation in elderly men. Atherosclerosis. 181, 201-207.

97. Herrera, E., Ortega, H., Alvino, G., Giovannini, N., Amusquivar, E. and Cetin, I. (2004) Relationship between plasma fatty acid profile and antioxidant vitamins during normal pregnancy. Eur $\mathrm{J}$ Clin Nutr. 58, 1231-1238.

98. Hodge, A.M., Simpson, J.A., Fridman, M., Rowley, K., English, D.R., Giles, G.G., Su, Q. and O'Dea, K. (2009) Evaluation of an FFQ for assessment of antioxidant intake using plasma biomarkers in an ethnically diverse population. Public Health Nutr. 12, $2438-2447$. 
99. $\mathrm{Hu}, \mathrm{G}$. and Cassano, P.A. (2000) Antioxidant nutrients and pulmonary function: the Third National Health and Nutrition Examination Survey (NHANES III). Am J Epidemiol. 151, 975-981.

100. Huerta, J.M., Gonzalez, S., Fernandez, S., Patterson, A.M. and Lasheras, C. (2004) No evidence for oxidative stress as a mechanism of action of hyperhomocysteinemia in humans. Free Radic Res. 38, $1215-1221$.

101. Huerta, J.M., Gonzalez, S., Fernandez, S., Patterson, A.M. and Lasheras, C. (2006) Lipid peroxidation, antioxidant status and survival in institutionalised elderly: a five-year longitudinal study. Free Radic Res. 40, 571-578.

102. Hughes, K., Lee, B.L., Feng, X., Lee, J. and Ong, C.N. (2002) Coenzyme Q10 and differences in coronary heart disease risk in Asian Indians and Chinese. Free Radic Biol Med. 32, 132-138.

103. Iannuzzi, A., Celentano, E., Panico, S., Galasso, R., Covetti, G., Sacchetti, L., Zarrilli, F., De Michele, M. and Rubba, P. (2002) Dietary and circulating antioxidant vitamins in relation to carotid plaques in middle-aged women. Am J Clin Nutr. 76, 582-587.

104. Ilow, R., Regulska-Ilow, B., Rozanska, D., Zatonska, K., Dehghan, M., Zhang, X., Szuba, A., Vatten, L., Janik-Koncewicz, K., Manczuk, M. and Zatonski, W.A. (2011) Evaluation of mineral and vitamin intake in the diet of a sample of Polish population - baseline assessment from the prospective cohort 'PONS' study. Ann Agric Environ Med. 18, 235-240.

105. Iwasaki, M., Manz, M.C., Taylor, G.W., Yoshihara, A. and Miyazaki, H. (2012) Relations of serum ascorbic acid and alpha-tocopherol to periodontal disease. J Dent Res. 91, 167-172.

106. Jain, S.K., Wise, R., Yanamandra, K., Dhanireddy, R. and Bocchini, J.A., Jr. (2008) The effect of maternal and cord-blood vitamin $\mathrm{C}$, vitamin $\mathrm{E}$ and lipid peroxide levels on newborn birth weight. Mol Cell Biochem. 309, 217-221.

107. Jenab, M., Salvini, S., van Gils, C.H., Brustad, M., Shakya-Shrestha, S., Buijsse, B., Verhagen, H., Touvier, M., Biessy, C., Wallstrom, P., Bouckaert, K., Lund, E., Waaseth, M., Roswall, N., Joensen, A.M., Linseisen, J., Boeing, H., Vasilopoulou, E., Dilis, V., Sieri, S., Sacerdote, C., Ferrari, P., Manjer, J., Nilsson, S., Welch, A.A., Travis, R., Boutron-Ruault, M.C., Niravong, M., Bueno-de-Mesquita, H.B., van der Schouw, Y.T., Tormo, M.J., Barricarte, A., Riboli, E. Bingham, S. and Slimani, N. (2009) Dietary intakes of retinol, beta-carotene, vitamin $\mathrm{D}$ and vitamin $\mathrm{E}$ in the European Prospective Investigation into Cancer and Nutrition cohort. Eur J Clin Nutr. 63(Suppl 4), S150-S178.
108. Junior,E.V.,Cesar, C.L.,Fisberg, R.M. and Marchioni, D.M. (2011) Socio-economic variables influence the prevalence of inadequate nutrient intake in Brazilian adolescents: results from a population-based survey. Public Health Nutr. 14, 1533-1538.

109. Kang, M.J., Lin, Y.C., Yeh, W.H. and Pan, W.H. (2004) Vitamin E status and its dietary determinants in Taiwanese-results of the Nutrition and Health Survey in Taiwan 1993-1996. Eur J Nutr. 43, 86-92.

110. Kant, A.K. and Graubard, B.I. (2008) Ethnic and socioeconomic differences in variability in nutritional biomarkers. Am J Clin Nutr. 87, 1464-1471.

111. Kato, Y., Ikehara, S., Maruyama, K., Inagawa, M., Oshima, M., Yokota, K., Yamazaki, T., Kishi, M., Murai, S., Umesawa, M., Ma, E., Yamagishi, K., Tanigawa, T., Kurokawa, M., Sato, S., Shimamoto, T. and Iso, H. (2009) Trends in dietary intakes of vitamins $\mathrm{A}, \mathrm{C}$ and $\mathrm{E}$ among Japanese men and women from 1974 to 2001. Public Health Nutr. 12, $1343-1350$.

112. Kelly, Y., Sacker, A. and Marmot, M. (2003) Nutrition and respiratory health in adults: findings from the health survey for Scotland. Eur Respir J. 21, 664-671.

113. Kelvin, E.A., Edwards, S., Jedrychowski, W., Schleicher, R.L., Camann, D., Tang, D. and Perera, F.P. (2009) Modulation of the effect of prenatal PAH exposure on PAH-DNA adducts in cord blood by plasma antioxidants. Cancer Epidemiol Biomarkers Prev. 18, 2262-2268.

114. Khalil, A., Gaudreau, P., Cherki, M., Wagner, R., Tessier, D.M., Fulop, T. and Shatenstein, B. (2011) Antioxidant-rich food intakes and their association with blood total antioxidant status and vitamin $\mathrm{C}$ and $\mathrm{E}$ levels in community-dwelling seniors from the Quebec longitudinal study NuAge. Exp Gerontol. 46, 475-481.

115. Kharb, S., Singh, G.P., Ghalaut, V.S. and Yadav, J. (2006) Plasma tocopherol levels: a preliminary reference range. J Indian Med Assoc. 104, 80, 84.

116. Khatib, I.M. and Elmadfa, I. (2009) High prevalence rates of anemia, vitamin $\mathrm{A}$ deficiency and stunting imperil the health status of Bedouin schoolchildren in North Badia, Jordan. Ann Nutr Metab. 55, 358-367.

117. Khatib, I.M. and Elmadfa, I. (2009) Poor nutritional health of Bedouin preschool children in Jordan: the irony of urbanization. Ann Nutr Metab. 54, 301-309.

118. Kieu, N.T., Yurie, K., Hung, N.T., Yamamoto, S. and Chuyen, N.V. (2002) Simultaneous analysis of retinol, beta-carotene and tocopherol levels in serum of Vietnamese populations with different incomes. Asia Pac J Clin Nutr. 11, 92-97. 
119. Klapcinska, B., Derejczyk, J., Wieczorowska-Tobis, K., Sobczak, A., Sadowska-Krepa, E. and Danch, A. (2000) Antioxidant defense in centenarians (a preliminary study). Acta Biochim Pol. 47, 281-292.

120. Kompauer, I., Heinrich, J., Wolfram, G. and Linseisen, J. (2006) Association of carotenoids, tocopherols and vitamin $\mathrm{C}$ in plasma with allergic rhinitis and allergic sensitisation in adults. Public Health Nutr. 9, 472-479.

121. Krummel, D.A., Gordon, P., Newcomer, R.R., Lui, X., Christy, D.M. and Holmes, A. (2001) Dietary intakes and leisure-time physical activity in West Virginians. W V Med J. 97, 295-301.

122. Lako, J.V. and Nguyen, V.C. (2001) Dietary patterns and risk factors of diabetes mellitus among urban indigenous women in Fiji. Asia Pac J Clin Nutr. 10, 188-193.

123. Lasheras, C., Huerta, J.M., Gonzalez, S., Brana, A.F., Patterson, A.M. and Fernandez, S. (2002) Independent and interactive association of blood antioxidants and oxidative damage in elderly people. Free Radic Res. 36, 875-882.

124. Leeson, C.P., Mann, A., Kattenhorn, M., Deanfield, J.E., Lucas, A. and Muller, D.P. (2002) Plasma vitamin $\mathrm{E}$, total antioxidant status and vascular function in young adults. Eur J Clin Invest. 32, 889-894.

125. Lengyel, C.O., Whiting, S.J. and Zello, G.A. (2008) Nutrient inadequacies among elderly residents of long-term care facilities. Can J Diet Pract Res. 69, $82-88$.

126. Leotsinidis, M., Alexopoulos, A., Schinas, V., Kardara, M. and Kondakis, X. (2000) Plasma retinol and tocopherol levels in greek elderly population from an urban and a rural area: associations with the dietary habits. Eur J Epidemiol. 16, 1009-1016.

127. Lewis, S.M., Mayhugh, M.A., Freni, S.C., Thorn, B., Cardoso, S., Buffington, C., Jairaj, K. and Feuers, R.J. (2003) Assessment of antioxidant nutrient intake of a population of southern US African-American and Caucasian women of various ages when compared to dietary reference intakes. J Nutr Health Aging. 7, $121-128$.

128. Macdonald, H.M., New, S.A., Golden, M.H., Campbell, M.K. and Reid, D.M. (2004) Nutritional associations with bone loss during the menopausal transition: evidence of a beneficial effect of calcium, alcohol, and fruit and vegetable nutrients and of a detrimental effect of fatty acids. Am J Clin Nutr. 79, $155-165$.

129. Manios, Y., Grammatikaki, E., Papoutsou, S., Liarigkovinos, T., Kondaki, K. and Moschonis, G. (2008) Nutrient intakes of toddlers and preschoolers in Greece: the GENESIS study. J Am Diet Assoc. 108, 357-361.

130. Maras, J.E., Bermudez, O.I., Qiao, N., Bakun, P.J., Boody-Alter, E.L. and Tucker, K.L. (2004) Intake of alpha-tocopherol is limited among US adults. J Am Diet Assoc. 104, 567-575.

131. Masters, E.T., Jedrychowski, W., Schleicher, R.L., Tsai, W.Y., Tu, Y.H., Camann, D., Tang, D. and Perera, F.P. (2007) Relation between prenatal lipidsoluble micronutrient status, environmental pollutant exposure, and birth outcomes. Am J Clin Nutr. 86, $1139-1145$.

132. McKeever, T.M., Lewis, S.A., Smit, H., Burney, P., Britton, J. and Cassano, P.A. (2004) Serum nutrient markers and skin prick testing using data from the Third National Health and Nutrition Examination Survey. J Allergy Clin Immunol. 114, 1398-1402.

133. McKeever, T.M., Lewis, S.A., Smit, H.A., Burney, P., Cassano, P.A. and Britton, J. (2008) A multivariate analysis of serum nutrient levels and lung function. Respir Res. 9, 67.

134. McQuillan, B.M., Hung, J., Beilby, J.P., Nidorf, M. and Thompson, P.L. (2001) Antioxidant vitamins and the risk of carotid atherosclerosis. The Perth Carotid Ultrasound Disease Assessment study (CUDAS). J Am Coll Cardiol. 38, 1788-1794.

135. Mensink, G.B. and Beitz, R. (2004) Food and nutrient intake in East and West Germany, 8 years after the reunification. The German Nutrition Survey 1998. Eur J Clin Nutr. 58, 1000-1010.

136. Metcalf, P.A., Scragg, R.K., Stewart, A.W. and Scott, A.J. (2007) Design effects associated with dietary nutrient intakes from a clustered design of 1- to 14-year-old children. Eur J Clin Nutr. 61, 1064-1071.

137. Morris, M.C., Evans, D.A., Bienias, J.L., Tangney, C.C. and Wilson, R.S. (2002) Vitamin E and cognitive decline in older persons. Arch Neurol. 59, 1125-1132.

138. Nakano, T., Fediuk, K., Kassi, N. and Kuhnlein, H.V. (2005) Food use of Dene/Metis and Yukon children. Int J Circumpolar Health. 64, 137-146.

139. Neuhouser, M.L., Patterson, R.E., King, I.B., Horner, N.K. and Lampe, J.W. (2003) Selected nutritional biomarkers predict diet quality. Public Health Nutr. 6, 703-709.

140. Neuhouser, M.L., Rock, C.L., Eldridge, A.L., Kristal, A.R., Patterson, R.E., Cooper, D.A., NeumarkSztainer, D., Cheskin, L.J. and Thornquist, M.D. (2001) Serum concentrations of retinol, alphatocopherol and the carotenoids are influenced by diet, race and obesity in a sample of healthy adolescents. J Nutr. 131, 2184-2191. 
141. O'Brien, M.M., Kiely, M., Harrington, K.E., Robson, P.J., Strain, J.J. and Flynn, A. (2001) The North/ South Ireland Food Consumption Survey: vitamin intakes in 18-64-year-old adults. Public Health Nutr. 4, 1069-1079.

142. Obeid, O.A., Al-Ghali, R.M., Khogali, M. and Hwalla, N. (2006) Vitamins A and E status in an urban Lebanese population: a case study at Dar AlFatwa area, Beirut. Int J Vitam Nutr Res. 76, 3-8.

143. Obuseh, F.A., Jolly, P.E., Jiang, Y., Shuaib, F.M., Waterbor, J., Ellis, W.O., Piyathilake, C.J., Desmond, R.A., Afriyie-Gyawu, E. and Phillips, T.D. (2010) Aflatoxin B1 albumin adducts in plasma and aflatoxin M1 in urine are associated with plasma concentrations of vitamins A and E. Int J Vitam Nutr Res. 80, 355-368.

144. Ogata, M., Kuriyama, S., Sato, Y., Shimazu, T., Nakaya, N., Ohmori, K., Hozawa, A. and Tsuji, I. (2006) Impact of non-dietary nutrients intake on misclassification in the estimation of nutrient intake in epidemiologic study. J Epidemiol. 16, 193-200.

145. Oishi, J., Doi, H. and Kawakami, N. (2009) Nutrition and depressive symptoms in community-dwelling elderly persons in Japan. Acta Med Okayama. 63, 9-17.

146. Okuda, M., Sasaki, S., Bando, N., Hashimoto, M., Kunitsugu, I., Sugiyama, S., Terao, J. and Hobara, T. (2009) Carotenoid, tocopherol, and fatty acid biomarkers and dietary intake estimated by using a brief self-administered diet history questionnaire for older Japanese children and adolescents. J Nutr Sci Vitaminol (Tokyo). 55, 231-241.

147. Palli, D., Masala, G., Vineis, P., Garte, S., Saieva, C., Krogh, V., Panico, S., Tumino, R., Munnia, A., Riboli, E. and Peluso, M. (2003) Biomarkers of dietary intake of micronutrients modulate DNA adduct levels in healthy adults. Carcinogenesis. 24, 739-746.

148. Patel, S., Murray, C.S., Woodcock, A., Simpson, A. and Custovic, A. (2009) Dietary antioxidant intake, allergic sensitization and allergic diseases in young children. Allergy. 64, 1766-1772.

149. Pearson, P., Britton, J., McKeever, T., Lewis, S.A., Weiss, S., Pavord, I. and Fogarty, A. (2005) Lung function and blood levels of copper, selenium, vitamin $\mathrm{C}$ and vitamin $\mathrm{E}$ in the general population. Eur J Clin Nutr. 59, 1043-1048.

150. Phillips, E.L., Arnett, D.K., Himes, J.H., McGovern, P.G., Blackburn, H. and Luepker, R.V. (2000) Differences and trends in antioxidant dietary intake in smokers and non-smokers, 1980-1992: the Minnesota Heart Survey. Ann Epidemiol. 10, 417-423.
151. Pinheiro,M.M.,Ciconelli,R.M.,Chaves,G.V.,Aquino, L., Juzwiak, C.R., Genaro Pde, S. and Ferraz, M.B. (2011) Antioxidant intake among Brazilian adults - the Brazilian Osteoporosis Study (BRAZOS): a cross-sectional study. Nutr J. 10, 39.

152. Ponka, R. and Fokou, E. (2011) Dietary intake, zincemia and cupremia of Cameroonian schoolchildren of Ngali II. Int J Food Sci Nutr. 62, 377-384.

153. Prynne, C.J., Paul, A.A., Mishra, G.D., Greenberg, D.C. and Wadsworth, M.E. (2005) Changes in intake of key nutrients over 17 years during adult life of a British birth cohort. Br J Nutr. 94, 368-376.

154. Ravaglia, G., Forti, P., Lucicesare, A., Pisacane, N., Rietti, E., Mangialasche, F., Cecchetti, R., Patterson, C. and Mecocci, P. (2008) Plasma tocopherols and risk of cognitive impairment in an elderly Italian cohort. Am J Clin Nutr. 87, 1306-1313.

155. Ravaglia, G., Forti, P., Maioli, F., Bastagli, L., Facchini, A., Mariani, E., Savarino, L., Sassi, S., Cucinotta, D. and Lenaz, G. (2000) Effect of micronutrient status on natural killer cell immune function in healthy free-living subjects aged $\geq 90$ y. Am J Clin Nutr. 71, $590-598$.

156. Requejo, A.M., Andres, P., Redondo, M.R., Mena, M.C., Navia, B., Perea, J.M., Lopez-Sobaler, A.M. and Ortega, R.M. (2002) Vitamin E status in a group of elderly people from Madrid. J Nutr Health Aging. 6, 72-74.

157. Rubin, R.N., Navon, L. and Cassano, P.A. (2004) Relationship of serum antioxidants to asthma prevalence in youth. Am J Respir Crit Care Med. 169, 393-398.

158. Ruggiero, C., Cherubini, A., Guralnik, J., Semba, R.D., Maggio, M., Ling, S.M., Lauretani, F., Bandinelli, S., Senin, U. and Ferrucci, L. (2007) The interplay between uric acid and antioxidants in relation to physical function in older persons. J Am Geriatr Soc. 55, 1206-1215.

159. Sahni, S., Hannan, M.T., Gagnon, D., Blumberg, J., Cupples, L.A., Kiel, D.P. and Tucker, K.L. (2008) High vitamin $\mathrm{C}$ intake is associated with lower 4-year bone loss in elderly men. J Nutr. 138, 1931-1938.

160. Sanchez-Vera, I., Bonet, B., Viana, M. and Sanz, C. (2004) Relationship between alpha-tocopherol content in the different lipoprotein fractions in term pregnant women and in umbilical cord blood. Ann Nutr Metab. 48, 146-150.

161. Sausenthaler, S., Loebel, T., Linseisen, J., Nagel, G., Magnussen, H. and Heinrich, J. (2009) Vitamin E intake in relation to allergic sensitization and $\mathrm{IgE}$ 
serum concentration. Cent Eur J Public Health. 17, 79-85.

162. Scaife, A.R., McNeill, G., Campbell, D.M., Martindale, S., Devereux, G. and Seaton, A. (2006) Maternal intake of antioxidant vitamins in pregnancy in relation to maternal and fetal plasma levels at delivery. Br J Nutr. 95, 771-778.

163. Scheurig, A.C., Thorand, B., Fischer, B., Heier, M. and Koenig, W. (2008) Association between the intake of vitamins and trace elements from supplements and C-reactive protein: results of the MONICA/KORA Augsburg study. Eur J Clin Nutr. 62, 127-137.

164. Schröder, H., Elosua, R. and Marrugat, J. (2003) The relationship of physical activity with dietary cancerprotective nutrients and cancer-related biological and lifestyle factors. Eur J Cancer Prev. 12, 339-346.

165. Schröder, H., Marrugat, J., Covas, M., Elosua, R., Pena, A., Weinbrenner, T., Fito, M., Vidal, M.A., Masia, R; REGICOR Investigators (2004) Population dietary habits and physical activity modification with age. Eur J Clin Nutr. 58, 302-311.

166. Schroder, H., Marrugat, J., Elosua, R. and Covas, M.I. (2002) Tobacco and alcohol consumption: impact on other cardiovascular and cancer risk factors in a southern European Mediterranean population. Br J Nutr. 88, 273-281.

167. Schulpis, K.H., Michalakakou, K., Gavrili, S., Karikas, G.A., Lazaropoulou, C., Vlachos, G., Bakoula, C. and Papassotiriou, I. (2004) Maternal-neonatal retinol and alpha-tocopherol serum concentrations in Greeks and Albanians. Acta Paediatr. 93, 1075-1080.

168. Schwarzpaul, S., Strassburg, A., Luhrmann, P.M. and Neuhauser-Berthold, M. (2006) Intake of vitamin and mineral supplements in an elderly german population. Ann Nutr Metab. 50, 155-162.

169. Sebastian, R.S., Cleveland, L.E., Goldman, J.D. and Moshfegh, A.J. (2007) Older adults who use vitamin/ mineral supplements differ from nonusers in nutrient intake adequacy and dietary attitudes. J Am Diet Assoc. 107, 1322-1332.

170. Serra-Majem, L., Pastor-Ferrer, M.C., Castell, C., Ribas-Barba, L., Roman-Vinas, B., Ribera, L.F., Plasencia, A. and Salleras, L. (2007) Trends in blood lipids and fat soluble vitamins in Catalonia, Spain (1992-2003). Public Health Nutr. 10, 1379-1388.

171. Serra-Majem, L., Ribas-Barba, L., Perez-Rodrigo, C. and Bartrina, J.A. (2006) Nutrient adequacy in Spanish children and adolescents. Br J Nutr. 96(Suppl 1), S49-S57.

172. Sette, S., Le Donne, C., Piccinelli, R., Arcella, D., Turrini, A., Leclercq, C; INRAN-SCAI 2005-06
Study Group (2011) The third Italian National Food Consumption Survey, INRAN-SCAI 2005-06 - part 1: nutrient intakes in Italy. Nutr Metab Cardiovasc Dis. 21, 922-932.

173. Shahar, D., Shai, I., Vardi, H., Brener-Azrad, A. and Fraser, D. (2003) Development of a semi-quantitative Food Frequency Questionnaire (FFQ) to assess dietary intake of multiethnic populations. Eur J Epidemiol. 18, 855-861.

174. Silvera, S.A., Jain, M., Howe, G.R., Miller, A.B. and Rohan, T.E. (2006) Carotenoid, vitamin A, vitamin $\mathrm{C}$, and vitamin $\mathrm{E}$ intake and risk of ovarian cancer: a prospective cohort study. Cancer Epidemiol Biomarkers Prev. 15, 395-397.

175. Sirivichayakul, C., Changbumrung, S., Chanthavanich, P., Moungnoi, P., Chokejindachai, W., Attanath, P. and Pengsaa, K. (2001) Plasma retinol and alphatocopherol level and growth indices of 7 months old healthy Thai infants in Bangkok. Southeast Asian J Trop Med Public Health. 32, 408-412.

176. Sobczak, A., Golka, D. and Szoltysek-Boldys, I. (2004) The effects of tobacco smoke on plasma alphaand gamma-tocopherol levels in passive and active cigarette smokers. Toxicol Lett. 151, 429-437.

177. Sofi, F., Vecchio, S., Giuliani, G., Martinelli, F., Marcucci, R., Gori, A.M., Fedi, S., Casini, A., Surrenti, C., Abbate, R. and Gensini, G.F. (2005) Dietary habits, lifestyle and cardiovascular risk factors in a clinically healthy Italian population: the 'Florence' diet is not Mediterranean. Eur J Clin Nutr. 59, 584-591.

178. Song, W.O. and Kerver, J.M. (2000) Nutritional contribution of eggs to American diets. J Am Coll Nutr. 19, 556S-562S.

179. Spankovich, C., Hood, L.J., Silver, H.J., Lambert, W., Flood, V.M. and Mitchell, P. (2011) Associations between diet and both high and low pure tone averages and transient evoked otoacoustic emissions in an older adult population-based study. J Am Acad Audiol. 22, 49-58.

180. Stahl, A., Vohmann, C., Richter, A., Heseker, H. and Mensink, G.B. (2009) Changes in food and nutrient intake of 6- to 17-year-old Germans between the $1980 \mathrm{~s}$ and 2006. Public Health Nutr. 12, 1912-1923.

181. Sundelof, J., Kilander, L., Helmersson, J., Larsson, A., Ronnemaa, E., Degerman-Gunnarsson, M., Sjogren, P., Basun, H., Lannfelt, L. and Basu, S. (2009) Systemic tocopherols and F2-isoprostanes and the risk of Alzheimer's disease and dementia: a prospective population-based study. J Alzheimers Dis. $18,71-78$.

182. Suwannalert, P., Boonsiri, P., Khampitak, T., Khampitak, K., Sriboonlue, P. and Yongvanit, P. 
(2007) The levels of lycopene, alpha-tocopherol and a marker of oxidative stress in healthy northeast Thai elderly. Asia Pac J Clin Nutr. 16(Suppl 1), 27-30.

183. Ta, T.M., Nguyen, K.H., Kawakami, M., Kawase, M. and Nguyen, C. (2003) Micronutrient status of primary school girls in rural and urban areas of South Vietnam. Asia Pac J Clin Nutr. 12, 178-185.

184. Tang, L., Xu, L., Afriyie-Gyawu, E., Liu, W., Wang, P., Tang, Y., Wang, Z., Huebner, H.J., Ankrah, N.A., Ofori-Adjei, D., Williams, J.H., Wang, J.S. and Phillips, T.D. (2009) Aflatoxin-albumin adducts and correlation with decreased serum levels of vitamins $\mathrm{A}$ and $\mathrm{E}$ in an adult Ghanaian population. Food Addit Contam Part A Chem Anal Control Expo Risk Assess. 26, 108-118.

185. Tekle, M., Gromadzinska, J., Joksic, G., Antic, R., Nilsson, R., Dallner, G., Unden, A.L. and Brismar, K. (2010) Plasma levels of insulin-like growth factor-I, insulin-like growth factor binding protein-1, coenzyme Q10 and vitamin E in female populations from Poland, Serbia and Sweden. Environ Int. 36, 188-194.

186. Tur, J.A., Colomer, M., Monino, M., Bonnin, T., Llompart, I. and Pons, A. (2005) Dietary intake and nutritional risk among free-living elderly people in Palma de Mallorca. J Nutr Health Aging. 9, 390-396.

187. Valachovicova, M., Krajcovicova-Kudlackova, M., Ginter, E. and Paukova, V. (2003) Antioxidant vitamins levels - nutrition and smoking. Bratisl Lek Listy. 104, 411-414.

188. Van Biervliet, S., Van Biervliet, J.P., Bernard, D., Matthys, M., Vercaemst, R. and Blaton, V. (2001) Serum alpha-tocopherol and selenium in Belgian infants and children. Biol Trace Elem Res. 79, $115-120$

189. van Leeuwen, R., Boekhoorn, S., Vingerling, J.R., Witteman, J.C., Klaver, C.C., Hofman, A. and de Jong, P.T. (2005) Dietary intake of antioxidants and risk of age-related macular degeneration. JAMA. 294, 3101-3107.

190. Vaquero, M.P., Sanchez-Muniz, F.J., Carbajal, A., Garcia-Linares, M.C., Garcia-Fernandez, M.C. and Garcia-Arias, M.T. (2004) Mineral and vitamin status in elderly persons from Northwest Spain consuming an Atlantic variant of the Mediterranean diet. Ann Nutr Metab. 48, 125-133.

191. Vikstedt, T., Suominen, M.H., Joki, A., Muurinen, S., Soini, H. and Pitkala, K.H. (2011) Nutritional status, energy, protein, and micronutrient intake of older service house residents. J Am Med Dir Assoc. 12, 302-307.

192. Walda, I.C., Tabak, C., Smit, H.A., Rasanen, L., Fidanza, F., Menotti, A., Nissinen, A., Feskens, E.J. and Kromhout, D. (2002) Diet and 20-year chronic obstructive pulmonary disease mortality in middleaged men from three European countries. Eur J Clin Nutr. 56, 638-643.

193. Waldmann, A., Koschizke, J.W., Leitzmann, C. and Hahn, A. (2005) Dietary intakes and blood concentrations of antioxidant vitamins in German vegans. Int J Vitam Nutr Res. 75, 28-36.

194. Wallstrom, P., Wirfalt, E., Lahmann, P.H., Gullberg, B., Janzon, L. and Berglund, G. (2001) Serum concentrations of beta-carotene and alpha-tocopherol are associated with diet, smoking, and general and central adiposity. Am J Clin Nutr. 73, 777-785.

195. Wang, Y., Hodge, A.M., Wluka, A.E., English, D.R., Giles, G.G., O'Sullivan, R., Forbes, A. and Cicuttini, F.M. (2007) Effect of antioxidants on knee cartilage and bone in healthy, middle-aged subjects: a crosssectional study. Arthritis Res Ther. 9, R66.

196. Wang, Y.Z., Ren, W.H., Liao, W.Q. and Zhang, G.Y. (2009) Concentrations of antioxidant vitamins in maternal and cord serum and their effect on birth outcomes. J Nutr Sci Vitaminol (Tokyo). 55, 1-8.

197. Watters, J.L., Satia, J.A. and Kupper, L.L. (2008) Correlates of antioxidant nutrients and oxidative DNA damage differ by race in a cross-sectional study of healthy African American and white adults. Nutr Res. 28, 565-576.

198. Watters, J.L., Satia, J.A., Kupper, L.L., Swenberg, J.A., Schroeder, J.C. and Switzer, B.R. (2007) Associations of antioxidant nutrients and oxidative DNA damage in healthy African-American and White adults. Cancer Epidemiol Biomarkers Prev. 16, 1428-1436.

199. Wengreen, H.J., Munger, R.G., Corcoran, C.D., Zandi, P., Hayden, K.M., Fotuhi, M., Skoog, I., Norton, M.C., Tschanz, J., Breitner, J.C. and Welsh-Bohmer, K.A. (2007) Antioxidant intake and cognitive function of elderly men and women: the Cache County Study. J Nutr Health Aging. 11, 230-237.

200. Wolters, M., Hermann, S., Golf, S., Katz, N. and Hahn, A. (2006) Selenium and antioxidant vitamin status of elderly German women. Eur J Clin Nutr. 60, $85-91$.

201. Wu, S.J., Chang, Y.H., Wei, I.L., Kao, M.D., Lin, Y.C. and Pan, W.H. (2005) Intake levels and major food sources of energy and nutrients in the Taiwanese elderly. Asia Pac J Clin Nutr. 14, 211-220.

202. Yilmaz, G., Isik Agras, P., Hizli, S., Karacan, C., Besler, H.T., Yurdakok, K. and Coskun, T. (2009) The effect of passive smoking and breast feeding on serum antioxidant vitamin $(\mathrm{A}, \mathrm{C}, \mathrm{E})$ levels in infants. Acta Paediatr. 98, 531-536. 
203. Zhang, X., Chen, K., Wei, X.P., Qu, P., Liu, Y.X., Chen, J. and Li, T.Y. (2009) Perinatal vitamin A status in relation to neurodevelopmental outcome at two years of age. Int J Vitam Nutr Res. 79, 238-249.

204. Zieden, B., Kaminskas, A., Kristenson, M., Olsson, A.G. and Kucinskiene, Z. (2002) Long chain polyunsaturated fatty acids may account for higher low-density lipoprotein oxidation susceptibility in Lithuanian compared to Swedish men. Scand J Clin Lab Invest. 62, 307-314.

205. Zillikens, M.C., van Meurs, J.B., Rivadeneira, F., Hofman, A., Oostra, B.A., Sijbrands, E.J., Witteman, J.C., Pols, H.A., van Duijn, C.M. and Uitterlinden, A.G. (2010) Interactions between dietary vitamin E intake and SIRT1 genetic variation influence body mass index. Am J Clin Nutr. 91, 1387--1393.

206. Pignitter, M., Stolze, K., Gartner, S., Dumhart, B., Stoll, C., Steiger, G., Kraemer, K. and Somoza, V. (2014) Cold fluorescent light as major inducer of lipid oxidation in soybean oil stored at household conditions for eight weeks. J Agric Food Chem. 62, 2297-2305.
207. Dror,D.K. and Allen,L.H.(2011)Vitamin Edeficiency in developing countries. Food Nutr Bull. 32, 124-143.

208. Valtuena, J., Breidenassel, C., Folle, J. and GonzalezGross, M. (2011) Retinol, beta-carotene, alphatocopherol and vitamin D status in European adolescents; regional differences an variability: a review. Nutr Hosp. 26, 280-288.

209. Heseker, H., Kohlmeier, M. and Schneider, R. (1993) [Lipid adjustment of alpha-tocopherol concentrations in plasma]. Z Ernahrungswiss. 32, 219-228.

210. Leonard, P.J., Doyle, E. and Harrington, W. (1972) Levels of vitamin $\mathrm{E}$ in the plasma of newborn infants and of the mothers. Am J Clin Nutr. 25, 480-484.

Szabolcs Péter M.D., Ph.D.

DSM Nutritional Products Ltd.

P.O. Box 2676

4002 Basel

Switzerland

Tel.: +41618158966

Fax: +41618158540

szabolcs.peter@dsm.com 